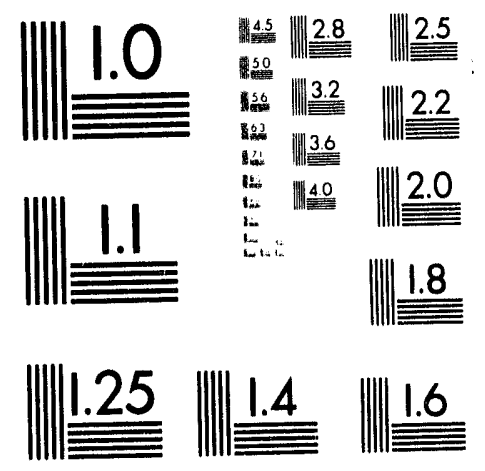



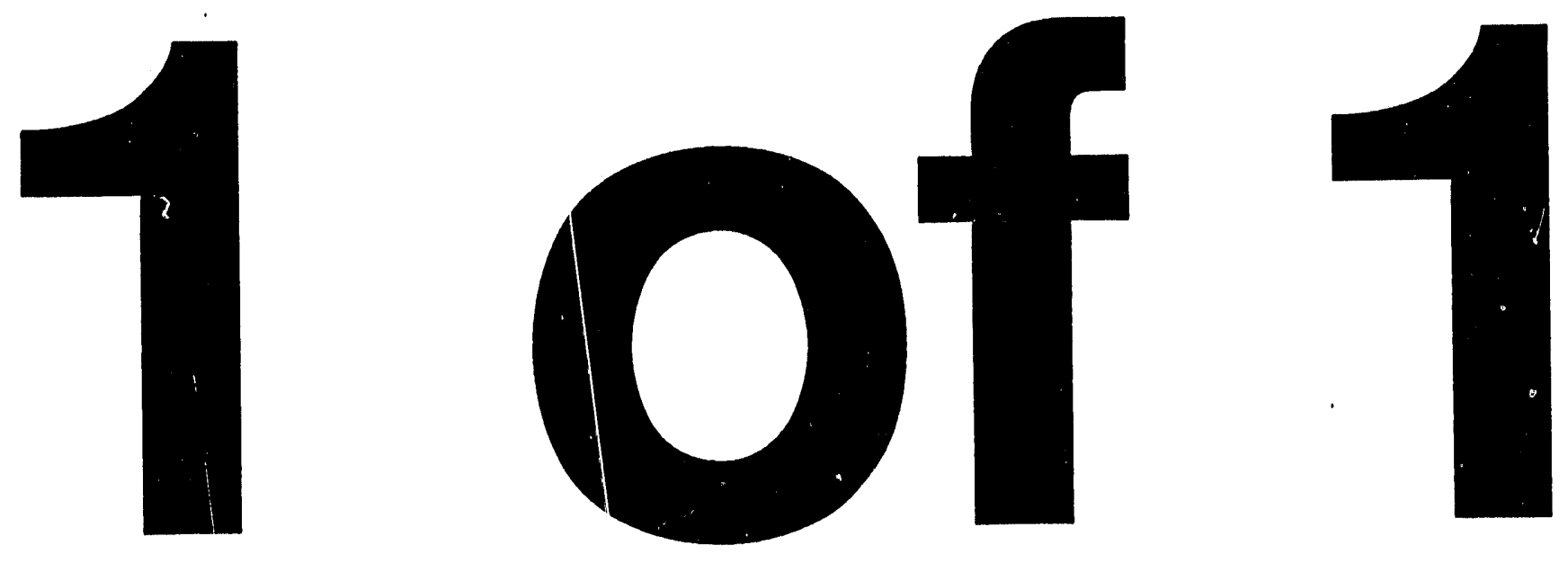


\title{
A STUDY OF RADON-222 CONCENTRATIONS IN NORTH CAROLINA GROUNDWATER
}

by

\author{
James Philip Evans
}

A Thesis submitted to the faculty of The University of North Carolina at Chapel Hill in partial fulfillment of the requirements for the degree of Master of Science in the Department of Environmental Sciences and Engineering, School of Public Health.

Chapel Hill

1992

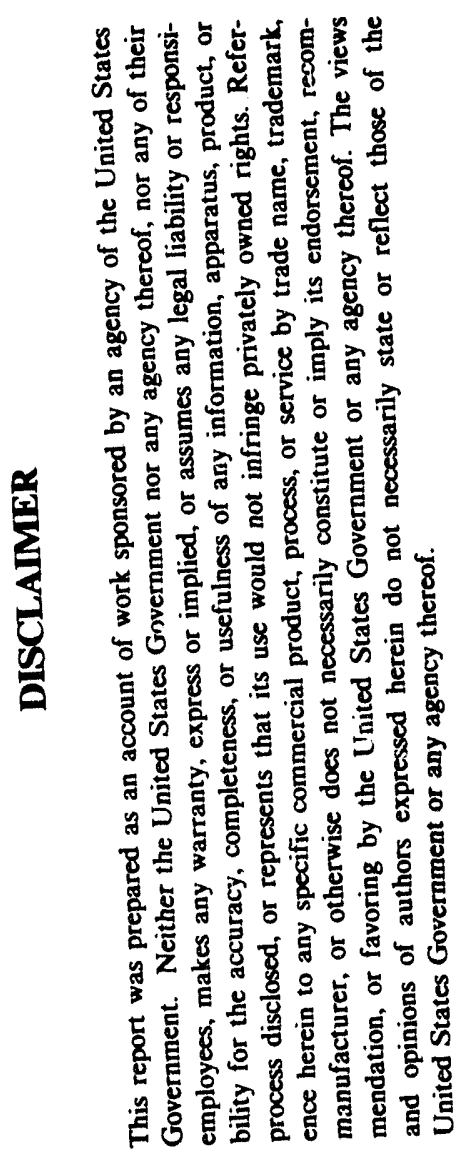

Approved by:

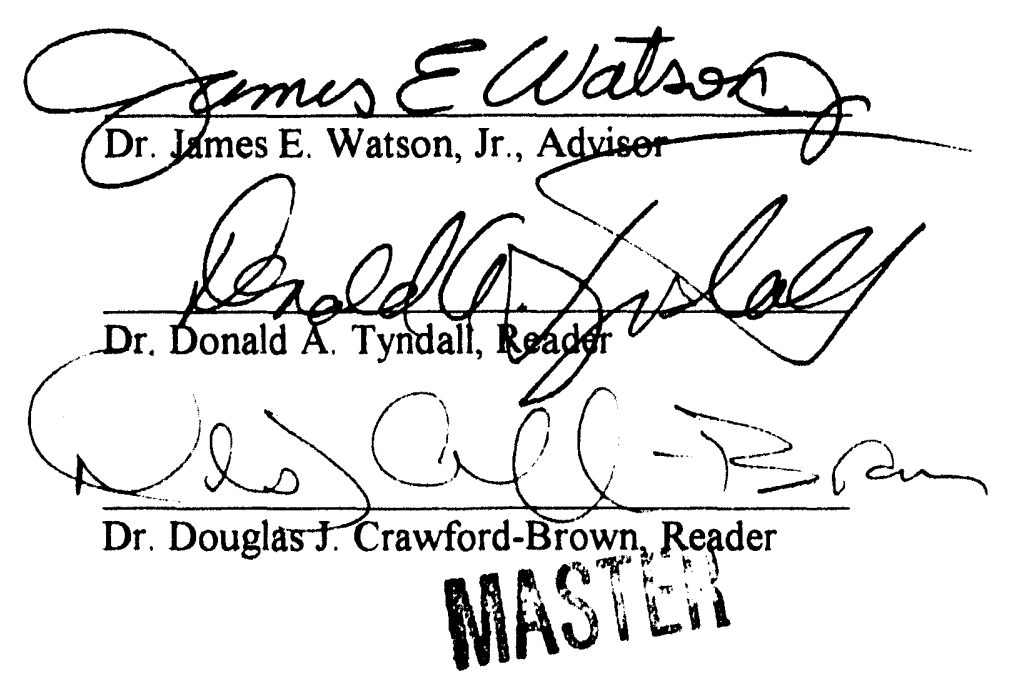

ato

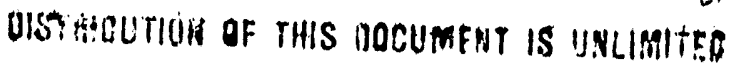


The Goverment reserves for itself and others acting on its behalf a royalty free, nonexclusive, irrevocable, world-wide license for govermental purposes to publish, distribute, translate, duplicate, exhibit, and perform any such data copyrighted by the contractor.

(C) 1992

James Philip Evans

ALL RIGHTS RESERVED 
JAMES PHILIP EVANS. A Study of Radon-222 Concentrations in North Carolina Groundwater (Under the direction of JAMES E. WATSON, JR.)

\begin{abstract}
The groundwater of 400 North Carolina homes was sampled to ascertain the distribution and extent of ${ }^{222} \mathrm{Rn}$ in North Carolina groundwater. Arithmetic mean (AM) and geometric mean $(\mathrm{GM})$ concentrations of $1,816 \mathrm{pCi} \mathrm{L}^{-1}$ and $656 \mathrm{pCi} \mathrm{L}^{-1}$ were found for the state. These results indicate that two-thirds of N.C. homes served by groundwater exceed the EPA proposed $300 \mathrm{pCi} \mathrm{L}^{-1}$ maximum contaminant level (MCL). Only $2 \%$ of N.C. homes exceeded $10,000 \mathrm{pCi} \mathrm{L}^{-1}$.

The Eastern region had the lowest radon concentrations by far, with a GM of 230 pCi L-1. The Central region and Western region had GM's of $794 \mathrm{pCi} \mathrm{L}^{-1}$ and 1,032 pCi $\mathrm{L}^{-1}$ respectively. The groundwater data approached a log normal distribution.

No consistent trends were noted in the relationship between indoor radon concentrations and groundwater radon concentrations. A correlation coefficient of 0.00921 revealed a very weak linear relationship.
\end{abstract}




\section{ACKNOWLEDGEMENTS}

This research was performed under appointment to the Operational Health Physics Fellowship Program administered by the Oak Ridge Institute for Science and Education for the United States Department of Energy.

Partial support for this research was provided by the North Carolina Department of Environmental Health and Natural Resources, Division of Radiation Protection.

I would like to thank Dr. Donald A. Tyndall and Dr. Douglas J. Crawford-Brown for their guidance and counsel. I especially want to thank Dr. James E. Watson, Jr., my advisor, for his leadership and foresight during the course of this research. I also wish to thank Mr. Allen M. Mabry for his help. Mr. Mabry collected and analyzed many of the groundwater samples.

Special thanks go to my family for their support during this time. Most of all I thank my wife, Anne. Her love, patience, and understanding made my work not only possible, but most enjoyable. I wish to dedicate this work to my son Alex, who aspires to be a scientist. May he experience the wondrous nature of the universe about him, as I have and continue to do. 


\section{TABLE OF CONTENTS}

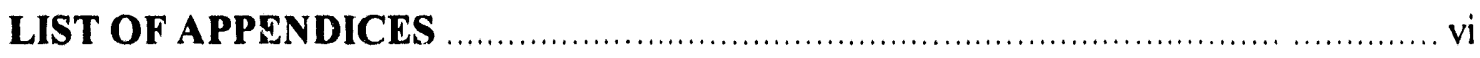

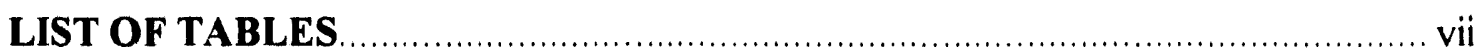

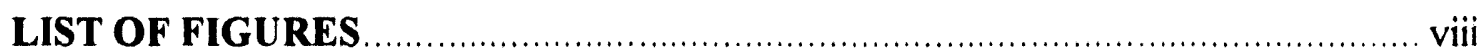

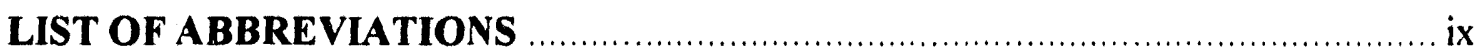

\section{CHAPTER}

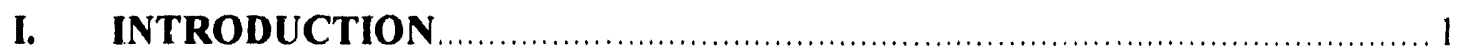

Importance of Radon Studies ............................................................. 1

Sources of Radon .............................................................................

Radon Regulations ........................................................................ 2

Survey Objectives ...................................................................... 2

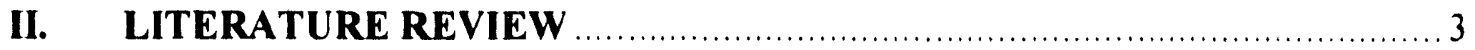

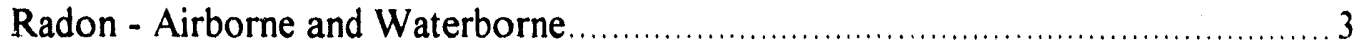

N.C. Regional Geology ........................................................................... 4

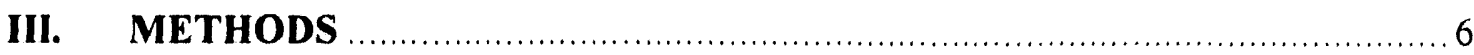

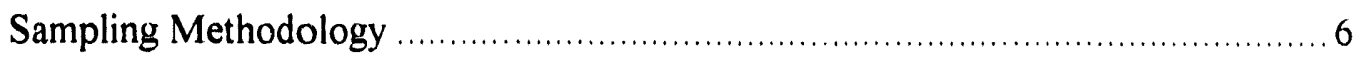

Sampling Instructions ..................................................................... 7

Sample Analysis .................................................................................. 7

Calibration Factors and Background Count Rates ...................................... 8

Minimum Detectable Activity .................................................................. 9

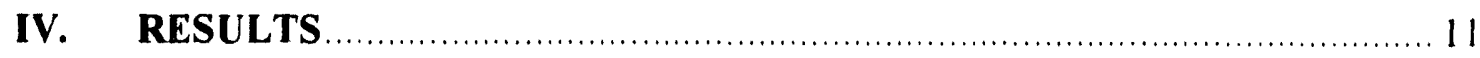

Weighting Factors …................................................................ 11

Statistics and Distribution of Data ................................................... 11

Analysis of Paired Water Samples .......................................................... 21

Analysis of Paired Air and Water Data ..................................................... 21

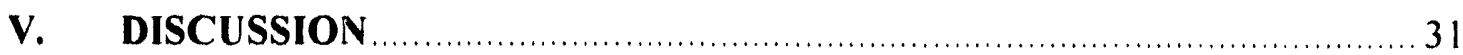

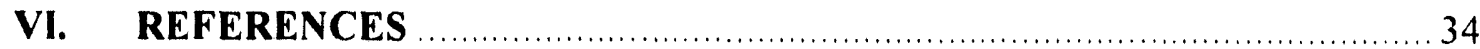




\section{LIST OF APPENDICES}

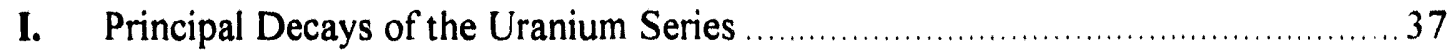

II. Mean Radon Concentrations and Number of Samples for N.C. Counties ............ 39

III. Homeowner Instruction Sheet for Obtaining Samples ............................... 43

IV. Packard Tri-Carb 300 Liquid Scintillation Counter Program Settings ................ 45

V. Calibration Factors and Background Count Rates for LSC Analysis ................47 47

VI. Data for Air and Water Radon Analysis ............................................. 50

VII. Data for Paired Water Sample Analysis ................................................. 61 


\section{LIST OF TABLES}

Table 1: Background and Calibration Factors. 8

Table 2: Groundwater Radon Survey Results 14 


\section{LIST OF FIGURES}

Figure 1: North Carolina Groundwater Radon Survey Regions ............................. 5

Figure 2: North Carolina Groundwater Radon Survey Counties Sampled and Counties Not Sampled

Figure 3: North Carolina Groundwater Radon Survey Regions and Counties Not Sampled.

Figure 4: Measures of Central Tendency 16

Figure 5: Proportion of Radon Concentrations Exceeding Specified Levels 17

Figure 6: N.C. Groundwater Radon Levels $\left(0-10,000 \mathrm{pCi} \mathrm{L}^{-1}\right)$ 18

Figure 7: Natural Log N.C. Groundwater Radon Levels 19

Figure 8: Distribution of N.C. Groundwater Radon 20

Figure 9: N.C. Eastern Region Groundwater Radon Levels 22

Figure 10: N.C. Central Region Groundwater Radon Levels $(0-10,000$ pCi L-1). 23

Figure 11: N.C. Western Region Groundwater Radon Levels $(0-10,000 \mathrm{pCi} \mathrm{L-1}) \ldots \ldots .24$

Figure 12: N.C. County Mean Groundwater Radon Concentrations. 25

Figure 13: Dual Samples - Pair Percent Differences 26

Figure 14: N.C. Groundwater Radon Concentrations vs Indoor Radon Concentrations.

Figure 15: N.C. Eastern Region Groundwater Radon Concentrations vs. Indoor Radon Concentrations.

Figure 16: N.C. Central Region Groundwater Radon Concentrations vs. Indoor Radon Concentrations 29

Figure 17: N.C. Western Region Groundwater Radon Concentrations vs. Indoor Radon Concentrations 


\section{ABBREVIATIONS}

a

b

$\lambda$

$214 \mathrm{Po}_{0}$

218Po

${ }^{222} \mathbf{R n}$

${ }^{226} \mathbf{R a}$

AM

ASD

AVBKG

AVGCF

B

BKG-

BKG-2

$B q L^{-1}$

CI

cpm

CPM-1

CPM-2

EPA

GM

GSD

k

$\mathrm{KeV}$

$\mathbf{L}$ probability of false signal detection

probability of false signal non-detection

radiological decay constant for $\operatorname{Radon}-222\left(1.8 \times 10^{-1}\right.$ days $\left.^{-1}\right)$

Polonium-214

Polonium-218

Radon-222

Radium-226

arithmetic mean

arithmetic standard deviation

average background from 2 blank water samples

average of the 2 Radium standard calibration factors

background count rate

counts per minute for blank water sample $\# 1$

counts per minute for blank water sample \#2

Becquerel per liter

confidence interval

counts per minute

gross counts per minute for Radium standard \#1

gross counts per minute for Radium standard $\# 2$

Environmental Protection Agency

yeometric mean

geometric standard deviation

value of standardized normal deviate $(1.64$ for $a=0.05)$

kilo electron volt

liter 


$\begin{array}{ll}\text { Lc } & \text { decision limit } \\ \mathbf{L}_{\mathbf{d}} & \text { detection limit } \\ \text { LSC } & \text { Liquid Scintillation Counter } \\ \text { MCL } & \text { maximum contaminant level } \\ \text { MDA } & \text { minimum detectable activity } \\ \text { MED } & \text { median } \\ \text { mI } & \text { milliliter } \\ \text { N.C. } & \text { North Carolina } \\ \text { pCi } & \text { picocurie } \\ \text { pCi L }-1 & \text { picocuries per liter } \\ \text { RTI } & \text { Research Triangle Institute } \\ \boldsymbol{t} & \text { elapsed time (from sample analysis) } \\ \mathbf{V} & \text { sample volume (in milliliters) } \\ \mathbf{X} & \text { net count rate (in counts per minute) } \\ \mathbf{Y} & \text { calibration factor (in counts per minute / picocurie) } \\ & \end{array}$




\section{INTRODUCTION}

\section{Importance of Radon Studies}

Concerns regarding indoor radon $\left({ }^{222} \mathrm{Rn}\right)$ have grown tremendously in the last few years. With the realization that radon comprises over half the average dose of radiation that people in the U.S. receive, many studies have been performed to a3certain the extent of radon in homes. Radon enters homes through two main pathways; first, it may seep from the soil or rock which lies under the home, and second, it may enter the home when water is used. Whenever faucets run, toilets flush, or clothes are washed, radon escapes from the incoming water. Some building materials (stone for example) also emit radon, but this is usually a small source and will not be addressed here.

Radon itself is not the problem. Radon is a partially water soluble, inert radioactive gas that is the progeny of ${ }^{226} \mathrm{Ra}$. The problem lies with the progeny of the decayed radon atom, 218Po and 214Po, which are alpha-emitters (Appendix I lists the Uranium decay series). The radon progeny are charged particles which may attach themselves to other particles in the air. The particles with attached progeny as well as unattached progeny are then inhaled, thus increasing the risks of developing lung cancer.

\section{Sources of Radon}

High concentrations of radon in groundwater are associated with granitic rocks and/or uranium bearing minerals like carnotite or uraninite (Hess et al. 1985). Physical factors such as pressure, temperature, and porosity of the host rock or soil control the rate of emissivity (movement) of radon. The radon diffuses through microcrystalline rock fractures and enters surrounding interstitial groundwater. Once in the groundwater, radon transport is generally governed by the groundwater percolation rate instead of diffusion (Hess et al. 1985). The radon then enters a home via the use of water from a well and/or works its way to the surface under a home and seeps in. 


\section{Radon Regulations}

The current action guide for radon in air is $4 \mathrm{pCi} \mathrm{L}^{-1}$ which corresponds to an estimated lifetime cancer risk of $1.5 \times 10^{-2}$ [1-5 in 100]. Radon in water is not currently regulated. However, the Environmental Protection Agency (EPA) has proposed a Maximum Contaminant Level (MCL) of $300 \mathrm{pCi} \mathrm{L}^{-1}$ for public water systems. The MCL is primarily based on the inhalation risk of radon emitted by water. On average, 10,000 $\mathrm{pCi} \mathrm{L}^{-1}$ of radon in water contributes about $1 \mathrm{pCi} \mathrm{L}^{-1}$ of radon to indoor air. At this rate, a $300 \mathrm{pCi} \mathrm{L}^{-1}$ level would contribute about $0.03 \mathrm{pCi} \mathrm{L}^{-1}$ of radon to home air. This level corresponds to an estimated lifetime cancer risk of approximately $2 \times 10^{-4}$ [2 in 10,000]. The risk associated with the radon MCL is consistent with those of other drinking water contaminants (USEPA 1991). The EPA believes the aforementioned levels for radon in water and indoor radon will protect the public to the highest degree feasible, given current radon mitigation strategies (USEPA 1991).

\section{Survey Objectives}

The State of North Carolina and the EPA performed a survey to characterize indoor ${ }^{222} \mathrm{Rn}$ levels for North Carolina during the period of February through April, 1990. The survey had two primary objectives; the first was to characterize the indoor radon distribution across the state, and the second was to identify areas with elevated indoor radon levels. Additionally, the information provided an estimation of mean indoor radon concentrations state wide and for geographical regions within the state (White et al. 1992). Barrier charcoal canisters were deployed for 48 hours using protocols recommended by the EPA (White, et al. 1992, USEPA 1986).

This report details a follow-up study (to the indoor radon survey) designed to investigate the distribution and extent of radon in North Carolina groundwater. The objectives of the groundwater radon survey are as follows:

- Examine the radon distribution in N.C. groundwater, state wide and by geographical region

- Estimate the mean concentrations of radon in N.C. groundwater

- Estimate the percentage of homes with radon concentrations above specified radon levels

- Study the relationship between groundwater radon concentrations and indoor radon concentrations. 


\section{LITERATURE REVIEW}

\section{$\underline{\text { Radon - Airborne and Waterborne }}$}

Groundwater accounts for less than $1 \%$ of the Earth's water. However, the amount of groundwater is 35 times greater than the volume of lakes and rivers on the Earth's surface (Flint and Skinner 1977). Out of nearly 60,000 public water supplies in the U.S., roughly $80 \%$ use groundwater sources. Of the groundwater supplies, over $90 \%$ serve 3,300 people or less (Hess et al. 1985). Estimates indicate that there are 13 million private wells in the U.S (Barron 1990).

There have been numerous studies performed on both indoor radon and groundwater radon in North Carolina. The aforementioned N.C. / EPA survey included nearly 1300 homes and found a mean indoor air concentration of $1.4 \mathrm{pCi} \mathrm{L}^{-1}$ for the state (White et al. 1992). Another study (Watson et al. 1988) revealed 63 counties (of 97 sampled) with no air measurement over $4 \mathrm{pCi} \mathrm{L}^{-1}$. Additionally, mean concentrations of $0.5 \mathrm{pCi} \mathrm{L}^{-1}, 2.1 \mathrm{pCi} \mathrm{L}^{-1}$, and $3.3 \mathrm{pCi} \mathrm{L}^{-1}$ were found for the Coastal Plain, Piedmont, and Mountains respectively. The highest concentrations were observed in the Mountains and western Piedmont.

Sasser and Watson (1978) studied 225 N.C. groundwater supplies and reported roughly one-third of the supplies with radon concentrations in excess of $2000 \mathrm{pCi} \mathrm{L}^{-1}$, with a maximum sample concentration of $46,600 \mathrm{pCi} \mathrm{L}^{-1}$. Radon in N.C. groundwater has been investigated for it's relationship to rock type and for the prediction of radon concentration (Loomis 1986, Rahlenbeck et al. 1991). It 'las been suggested that the radon concentration of water from private wells exceeds that of public utility water systems by a factor of 10 (Hess et al. 1985). However, another study by Loomis (1987) explored the inverse relationship between water-system size and ${ }^{222} \mathrm{Rn}$ concentration in N.C. public water supplies. Loomis suggests ihat the inverse relationship is a result of the differential distribution of water system sizes in areas of varying rock type (Loomis 1987). 
Michel (1990) also suggests the relationship between water system size and aquifer composition.

It is commonly suggested that a water radon concentration of $10,000 \mathrm{pCi} \mathrm{L}^{-1}$ will contribute an indoor concentrat in of $1 \mathrm{pCi} \mathrm{L}^{-1}$ in a home (Hess et al. 1985, Lawrence et al. 1992). The degassing of radon from water may contribute significantly to indoor radon. Some factors that may affect the radon contribution are home air exchange rate, water usage rates, and home air volume (Lawrence et al. 1992, Hess et al. 1985). The EPA states that waterborne radon is responsible for about $5 \%$ of the indoor radon nationally (USEPA 1991).

\section{N.C. Regional Geology}

The geological features of North Carolina are indeed diverse and are beyond the scope of this text. However, certain generalities are helpful when describing an area and its rock type. High radon concentrations are associated with granitic rocks. The crystalline structure of granitic rocks contains fractures which facilitate the diffusion of radon into the surrounding air and/or groundwater.

The Coastal Plain is characterized by clastic sediment (sand, silt, sandstones, and shales) underlain by metamorphic rock. There are also some limestones and fossil containing sediments (chemical sediments). Highly complex metamorphic rocks and granitic rocks compose the Piedmont. The Mountains contain an abundance of granitic rocks and metamorphic rocks. The survey regions are divided as follows, Eastern region, Central region, and Western region. The Eastern region closely follows the Coastal Plain, while the Central region contains the eastern Piedmont, and the Western region contains the western Piedmont and the Mountains. See Figure 1 for a North Carolina map of counties and regions. Appendix II lists the counties in each region. 
FIGURE 1: NORTH CAROLINA GROUNDWATER RADON SURVEY REGIONS

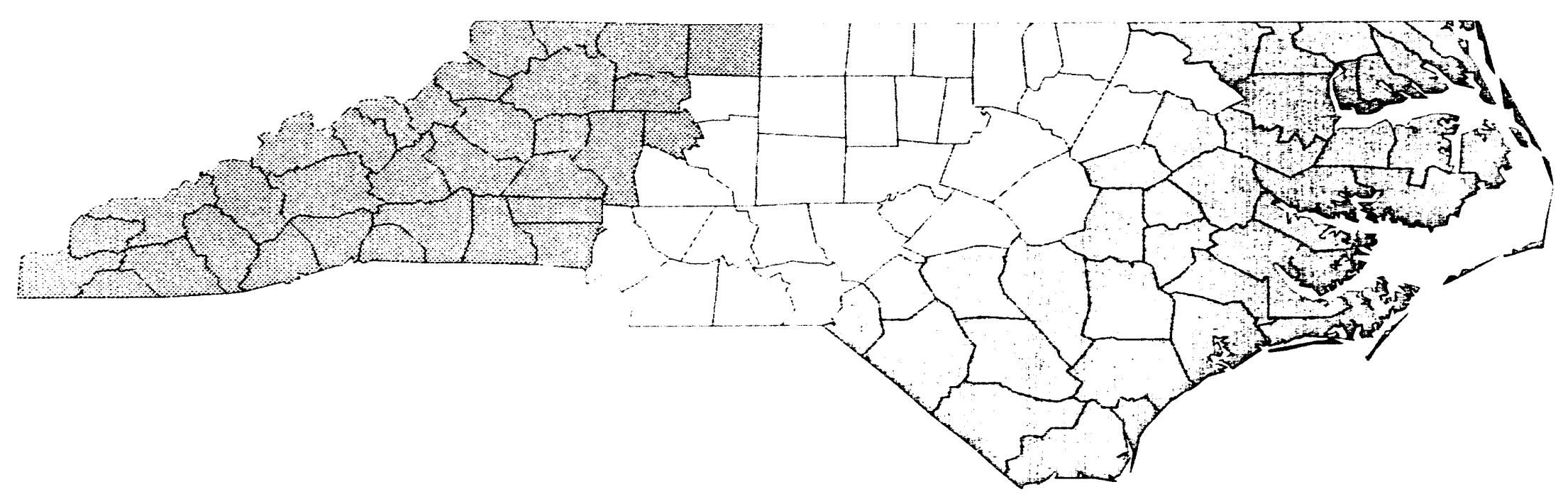

$\square$ EASTERN REGION

$\square$ CENTRAL REGION

$\square$ WESTERN REGION 


\section{METHODS}

\section{Sampling Methodology}

The aforementioned North Carolina / EPA indoor radon survey was designed by the Research Triangle Institute (RTI). RTI has coordinated similar surveys with the EPA for 29 other states (White et al. 1992). The survey results apply to a population of occupied dwellings with:

- A listed telephone number

- A permanent foundation

- At least one floor at or below grade level (including crawl spaces).

The homeowners that participated in the N.C. / EPA indoor radon survey responded to a questionnaire, which included one question that asked the source of their drinking water. The homeowners who identified a well as the source of their drinking water were contacted by letter asking for their participation in the follow-up groundwater radon study. The points emphasized in the homeowner letter were:

- Their previous participation in the indoor radon survey

- Confidentiality of individual results

- Groundwater radon concentration results will be provided to them at no cost.

The indoor radon questionnaire identified 558 homes that obtained their drinking water from wells. Further investigation revealed that 57 homes were ineligible for the study. Survey ineligibility arose from two major areas; homes that were not obtaining water from a well and homeowners who could not be contacted by mail or telephone follow-up methods. Barring any objections, homeowners were mailed sample kits containing two sample vials (for duplicate samples), a set of sampling instructions, a preaddressed return label with postage, and a reusable mailing container with packing material.

Homeowners from the 501 eligible homes returned 400 sample kits between November 1990 and August 1991. Attempts were made by follow-up letters and/or 
phone calls to contact homeowners who did not respond. Roughly $50 \%$ of the follow-up letters and/or phone calls led to a successful sample return. Homeowner non-response accounted for the 101 sample kits that were not returned. (Note: all homeowners for the groundwater radon survey were respondents in the previous indoor air radon survey.)

\section{Sampling Instructions}

Each homeowner received an explicit set of instructions for obtaining the water samples. Appendix III contains a copy of the actual instruction sheet. In brief, the instructions were the following:

- Check the contents of your mailing tube.

- Turn the COLD water on all the way and let it run for five (5) minutes.

- After five (5) minutes turn the water flow down to a slow stream.

- Carefully fill each vial to the neck; try not to overfill the vials.

- Immediately put the cap on each vial. Make sure the caps are tight.

- Record time and date on instruction sheet.

- Carefully wrap vials in the packing material and place in the mailing tube.

- Place instructions in tube - make sure you recorded time and date above.

- Attach the return label to the tube.

- Mail immediately.

\section{Sample Analysis}

Twenty $\mathrm{ml}$ liquid scintillation counting vials served as sample vials. Each sample vial was filled with $10 \mathrm{ml}$ of a non-hazardous mineral oil liquid scintillation fluid and weighed prior to homeowner distribution. The sample vials were re-weighed upon return to determine the mass, and hence volume of the water sample. An attempt was made to obtain duplicate samples from each homeowner, however, some vials broke or leaked during transit (see Results section). The results from all sample pairs were averaged for each home. When only an individual sample was available, it was also included in the analysis.

Sample counting was performed on a Packard Tri-Carb 300 liquid scintillation counter (LSC). The LSC was preprogrammed to count each sample for 50 minutes or until the percent deviation was down to 2 percent. The counting energy windows on the LSC were set for three ranges; 0 to $2000 \mathrm{KeV}$ for channel $\mathrm{A}, 5$ to $1850 \mathrm{KeV}$ for channel 
$B$, and 0 to $5 \mathrm{KeV}$ for channel C. Counts from channel $\mathrm{B}$ were used in the actual calculation of radon concentrations. (Appendix IV lists the settings for the LSC.)

Liquid scintillation vials were Kimble $20 \mathrm{ml}$ borosilicate glass vials with a coneshaped lid liner (Fisher Scientific catalog no. 03-337-7). The liquid scintillation counting fluid was DuPont High Efficiency Mineral Oil Scintillator (NEN Research Products catalog no. NEF 957A).

Prior to counting, all samples, standards, and blanks were each shaken vigorously for approximately 10 seconds to mix the aqueous and oil phases. The agitation of the sample preferentially dissolves the radon into the scintillation fluid (Horton 1983). The vials then sat at least 4 hours before counting to allow equilibration of the radon progeny.

\section{Calibration Factors and Background Count Rates}

A quality assurance check was performed each time the LSC was used. Two blank (distilled water) samples were counted to establish the average background (cpm) and two standards (sealed aqueous Radium-226 samples) were counted to obtain the calibration factor ( $\mathrm{cpm} \mathrm{pCi}{ }^{-1}$ ). The calibration factor (standard net count rate / standard activity) relates sample activity to count rate by analyzing a sample of known activity in the same way that experimental samples are analyzed. The sample net count rate is then divided by the calibration factor to yield sample activity. Table I lists the maximum, minimum, mean and standard deviation for background count rates and calibration factors. Appendix $V$ contains daily calibration factors and background count rates.

Table 1: Background and Calibration Factors

\begin{tabular}{|l|r|r|r|r|}
\hline & MEAN & STDEV & MAX & MIN \\
\hline BKG-1 & 30.96 & 1.18 & 33.00 & 28.04 \\
\hline BKG-2 & 30.50 & 1.06 & 33.16 & 28.48 \\
\hline AVBKG & 30.73 & 0.93 & 32.61 & 28.48 \\
\hline CPM-1 & 7294.34 & 101.96 & 7496.12 & 7045.25 \\
\hline CPM-2 & 9444.86 & 133.66 & 9726.00 & 9067.29 \\
\hline AVGCF & 10.03 & 0.12 & 10.24 & 9.67 \\
\hline
\end{tabular}

BKG-1 …..... Counts per minute for blank water sample \#1 (cpm)

BKG-2 ........ Counts per minute for biank water sample \#2 (cpm)

AVBKG ........ Average background from 2 blank water samples (cpm) 
CPM-1 ........ Gross counts per minute for $714 \mathrm{pCi} \mathrm{L}^{-1}$ Radium standard \#1 (cpm)

CPM-2 ........ Gross counts per minute for $952 \mathrm{pCi} \mathrm{L}^{-1}$ Radium standard \#2 (cpm)

AVGCF ....... Average of the 2 Radium standard calibration factors (cpm/pCi)

Radon concentrations in $\mathrm{pCi} \mathrm{L}^{-1}$ were then calculated from the LSC net count rates with the following relationship,

${ }^{222} \mathrm{Rn}$ concentration $(\mathrm{pCi} \mathrm{L}-1)=\frac{X}{Y} \frac{1000 \mathrm{ml} / \mathrm{L}}{\mathrm{V}} \exp (\lambda t)$

where: $\quad \mathrm{X}=$ Net Count Rate (cpm) [gross cpm minus background cpm]

$\mathrm{Y}=$ Calibration Factor $(\mathrm{cpm} / \mathrm{pCi})$

$\mathrm{V}=$ Sample Volume $(\mathrm{ml})$

$\lambda=$ Radiologi; al decay constant for ${ }^{222} \mathrm{Rn}\left(0.18\right.$ days $\left.{ }^{-1}\right)$

$t=$ Time elapsed from sample collection to midpoint of count (days).

\section{Minimum Detectable Activity}

Counting time and background levels determine the minimum detectable activity (MDA). Various terms are used to describe the MDA, however, the meaning of such terms is subject to different interpretations. NCRP 58 (1985) suggests two terms for describing the MDA; the decision limit $\left(L_{c}\right)$ and the detection limit $\left(L_{d}\right)$. The decision limit is the net number of counts (total minus background) for reaching a decision of signal non-detection (when actual net counts are less than $L_{c}$ ), or signal detection (when actual net counts are larger than $L_{c}$ ). The detection limit is a signal level such that a signal at or above this level is likely to be detected. The proportion of false detection (a) and the proportion of false non-detection (b) are both 0.05 , i.e., $95 \%$ confidence interval (C.I.). The formulae for $L_{c}$ and $L_{d}$ are as follows:

$$
\begin{array}{ll}
\mathrm{L}_{\mathrm{c}}=\mathrm{k} \sqrt{2} \sqrt{B} & \mathrm{~L}_{\mathrm{d}}=\mathrm{k}^{2}+2 \mathrm{~L}_{\mathrm{c}} \\
\mathrm{L}_{\mathrm{c}}=2.32 \sqrt{B} & \mathrm{~L}_{\mathrm{d}}=2.71+4.65 \sqrt{B}
\end{array}
$$

where: $\quad B=$ background counts

$k=1.64$, the value of the standardized normal deviate for the $95 \%$ C.I. 
The mean number of counts for the background was 1537 counts (during a 50 minute period). A typical calculation for the $\mathrm{L}_{\mathrm{c}}$ is as follows:

$$
\mathrm{L}_{\mathrm{c}}=2.32 \sqrt{B}=2.32 \frac{\sqrt{1537} \text { counts }}{50 \text { minutes }}=1.82 \mathrm{cpm}
$$

To convert the $L_{c}$ to a typical ${ }^{222} \mathrm{Rn}$ concentration, the following equation was used.

$L_{c}\left(p C i L^{-1}\right)=\frac{1.82 \mathrm{cpm}}{10.03 \mathrm{cpm} \mathrm{pCl}^{-1}} \frac{10(1) \mathrm{ml} / \mathrm{L}}{12.2 \mathrm{ml}} \exp \left(0.18\right.$ days $^{-1} \times 4.11$ days $)=31 \mathrm{pC} \mathrm{I} \mathrm{I}^{-1}$

Assuming: Mean calibration factor of $10.03 \mathrm{cpm} \mathrm{pCi}^{-1}$

Median sample volume of $12.2 \mathrm{ml}$

Median decay time of 4.11 days

${ }^{222} \mathrm{Rn}$ radiological decay constant of 0.18 days $^{-1}$

Results that were below the decision limit were included in calculations in order to avoid introduction of an unnecessary bias. 


\section{RESULTS}

As previously explained in the Methods section, 57 of the 558 homes initially identified were determined to be ineligible for the study. Of the 501 remaining homes, samples were collected from 400 . An attempt was made to obtain duplicate samples, and of the 400 homes surveyed, 364 provided duplicate samples. For the remaining 36 homes single samples were obtained due to broken or leaky sample vials. When duplicates were available, sample concentrations were determined by averaging the concentrations of each sample pair. Concentrations from duplicate and single samples were included in the groundwater radon analysis. There were $\mathbf{3 8 9}$ water samples that had a corresponding indoor radon concentration (from the N.C. / EPA survey).

\section{Weighting Factors}

Each home was assigned a discrete weight adjustment factor by RTi in the indoor radon survey (Bergsten et al. 1989). The weighting factors account for unequal probabilities of selection and are used to generate unbiased population estimates from the sample data. The western region of the state was sampled most heavily (277 samples), followed by the central ( 80 samples) and eastern ( 43 samples) regions. The weighted statistics are valid for an estimation of groundwater radon concentrations for North Carolina homes (served by groundwater) with a listed telephone number, a permanent foundation, and at least one floor at or below grade (including homes built over a crawl space). Non-weighted measures would reflect statistics for the samples only.

\section{Statistics and Distribution of Data}

Figures 2 and 3 show maps of the counties sampled and survey regions with counties sampled, respectively. Table 2 shows the statistics for the residential water samples. All statistics are calculated for North Carolina as a whoie, and for three geographic regions; Eastern, Central, and Western. The arithmetic mean (AM) concentration for the state is $1,816 \mathrm{pCi} \mathrm{L}^{-1}$, however the median (MED) and geometric 
GJTdWVS LON $\square$

ä7dWVS $\square$

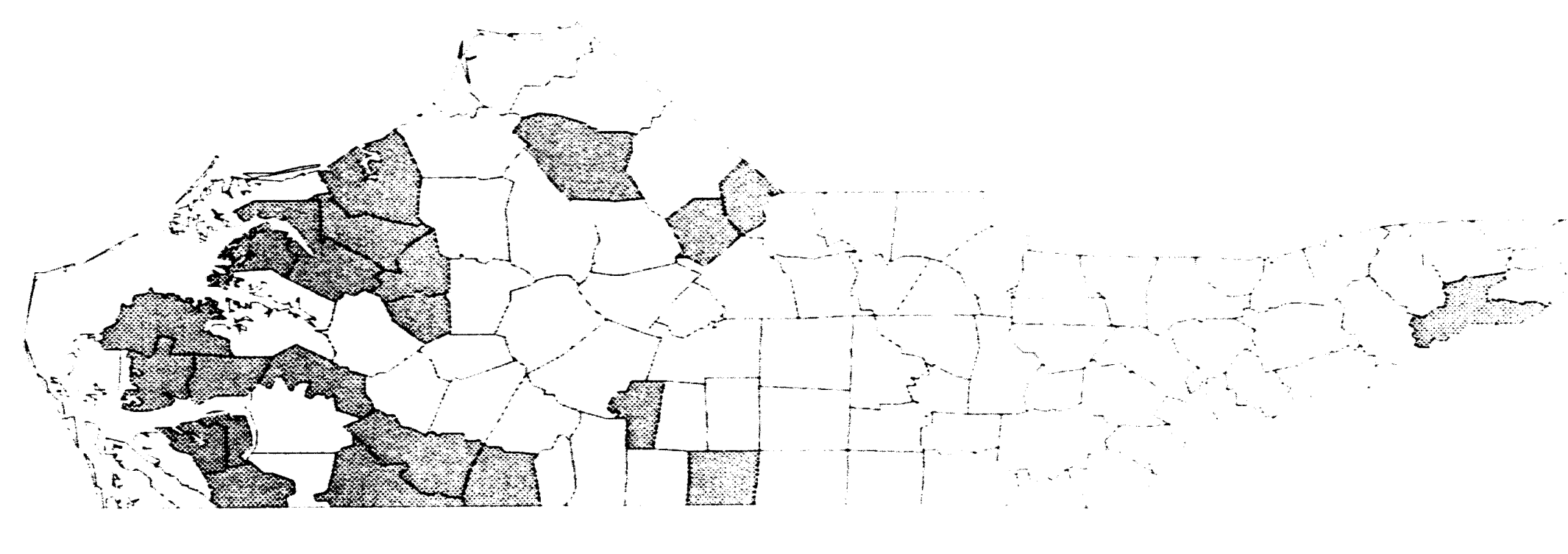

GTTdWVS LON SGILNIOD GNV GaTdWVS

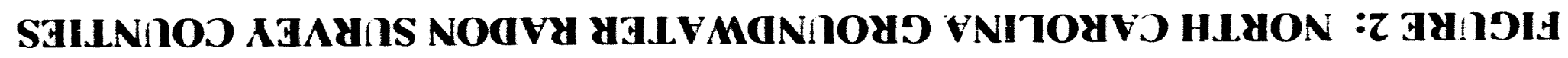


FIGURE 3: NORTH CAROLINA GROUNDWATER RADON SUIRVEY REGIONS AND COINTIES NOT SAMPLED
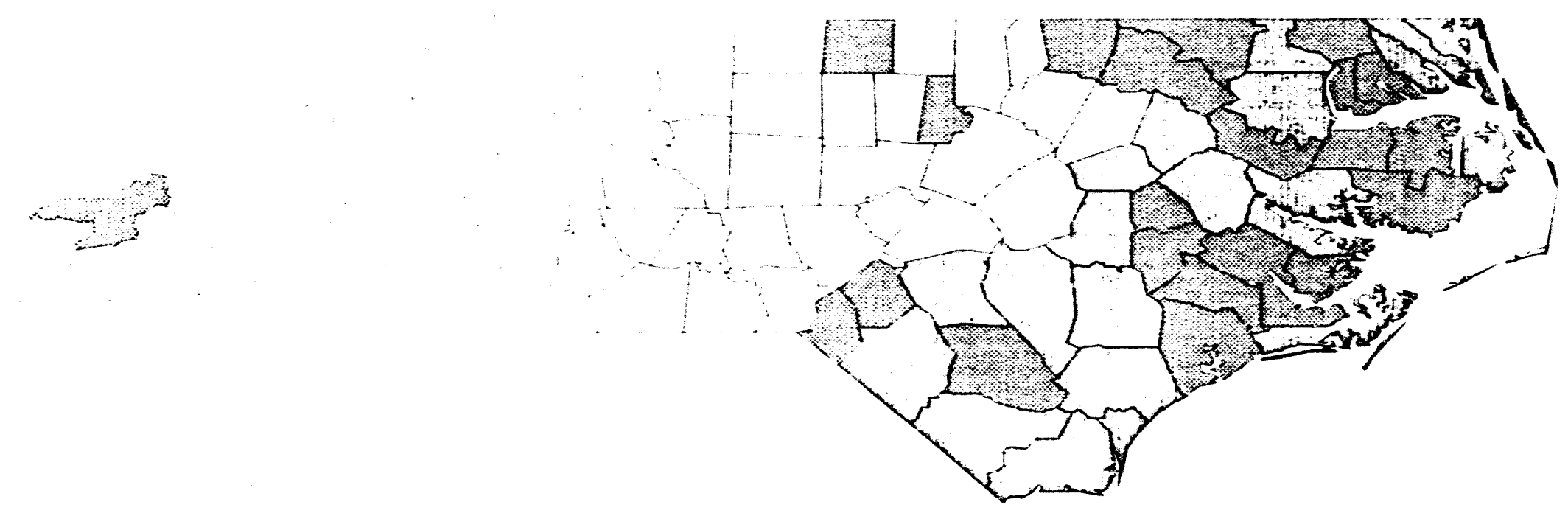

$\square$ EASTERN REGION

$\square$ CENTRAL REGION

$\square$ WESTERN REGION

$\square$ NOT SAMPLED 
Table 2 - Groundwater Radon Survey Results (pCi L-1)

\begin{tabular}{|l|c|c|c|c|}
\hline Region Sampled & State & Eastern & Central & Western \\
\hline Number of Homes Sampled & 400 & 43 & 80 & 277 \\
\hline Minimum Concentration & 9 & 67 & 9 & 21 \\
\hline Maximum Concentration & 59,088 & 1,715 & 19,558 & 59,088 \\
\hline Arithmetic Mean (AM) & 1,816 & 318 & 2,252 & 2,262 \\
\hline Arithmetic Standard Deviation (ASD) & $\pm 4,127$ & \pm 446 & $\pm 4,415$ & $\pm 5,005$ \\
\hline Median (MED) (50th percentile\} & 591 & 211 & 848 & 1,189 \\
\hline Geometric Mean (GM) & 656 & 230 & 794 & 1,032 \\
\hline Geometric Standard Deviation (GSD) & $\times \div 5.2$ & $\times \div 2.5$ & $\times \div 4.4$ & $\times \div 4.1$ \\
\hline \% Homes > 300 pCi L-1 & $67 \%$ & $30 \%$ & $75 \%$ & $83 \%$ \\
\hline \% Homes > 1,000 pCi L-1 & $37 \%$ & $5 \%$ & $38 \%$ & $56 \%$ \\
\hline Homes > 5,000 pCi L-1 10,000 pCi L-1 & $9 \%$ & $0 \%$ & $13 \%$ & $10 \%$ \\
\hline
\end{tabular}


mean (GM) are $591 \mathrm{pCi} \mathrm{L}^{-1}$ and $656 \mathrm{pCi} \mathrm{L}^{-1}$ respectively. The difference in the measures of central tendency helps illustrate the distribution of the data. Figure 4 depicts the measures of central tendency listed in Table 2. Clearly, the Eastern region has considerably lower concentrations than those of either the Central or Western regions. The Western and Central regions have similar arithmetic means of $2,262 \mathrm{pCi} \mathrm{L}^{-1}$ and $2,252 \mathrm{pCi} \mathrm{L}^{-1}$ respectively. However, their geometric means are $1,032 \mathrm{pCi} \mathrm{L}^{-1}$ and 794 $\mathrm{pCi} \mathrm{L}^{-1}$ respectively. Additionally, their respective medians are $1,189 \mathrm{pCi} \mathrm{L}^{-1}$ and $848 \mathrm{pCi}$ $\mathrm{L}^{-1}$. The $\mathrm{AM}$ is much more sensitive to extreme values than are the MED or GM.

A few very high concentrations tended to increase the AM. Figure 5 compares proportions of various radon concentrations for the state and regions (see bottom of Table 2 for values). A large number of homes have water radon concentrations in excess of the proposed EPA maximum contaminant level (MCL) of $300 \mathrm{pCi} \mathrm{L-1} ; 30 \%$ in the Eastern region, $75 \%$ in the Central region, and $83 \%$ in the Western Region. The combined regional figures revealed $67 \%$ of the state's homes in excess of the $300 \mathrm{pCi} \mathrm{L}-1 \mathrm{MCL}$ Ninety-five percent of the Eastern region homes had levels below $1,000 \mathrm{pCi} \mathrm{L-1}$, with none above $2,000 \mathrm{pCi} \mathrm{L}^{-1}$. The rest of the state presents a different picture though. The Central and Western regions have considerably higher radon concentrations than the Eastern region. The highest radon concentration $\left(59,088 \mathrm{pCi} \mathrm{L}^{-1}\right)$ was found in the Western region, while the highest Central region concentration was $19,558 \mathrm{pCi} \mathrm{L}^{-1}$. The Western region had a higher proportion of homes with greater than $1,000 \mathrm{pCi} \mathrm{L}^{-1}$ than did the Central region. Yet, the Central region had a higher proportion of homes exceeding the $5,000 \mathrm{pCi} \mathrm{L}^{-1}$ and $10,000 \mathrm{pCi} \mathrm{L}^{-1}$ categories than did the Western region. State wide, $98 \%$ of the homes had concentrations below $10,000 \mathrm{pCi} \mathrm{L}^{-1}$.

Figures 6 and 7 portray the distribution of the groundwater radon concentrations for the state. The radon concentrations are plotted in frequency distributions showing the respective proportion of homes per interval. Figure 6 clearly indicates that the data are not normally distributed. The data are strongly skewed in the positive direction. Figure 7 is similar to Figure 6 with the exception of the logarithmic axis for radon concentration. However, for this case the frequency distribution approaches that of a normal curve Lastly, Figure 8 depicts the cumulative percent versus log concentration for the groundwater radon data. Other studies have indicated the log normal distribution for their data (Hess et al. 1985, Longtin 1990). The middle area of the curve approximates a log normal distribution. 


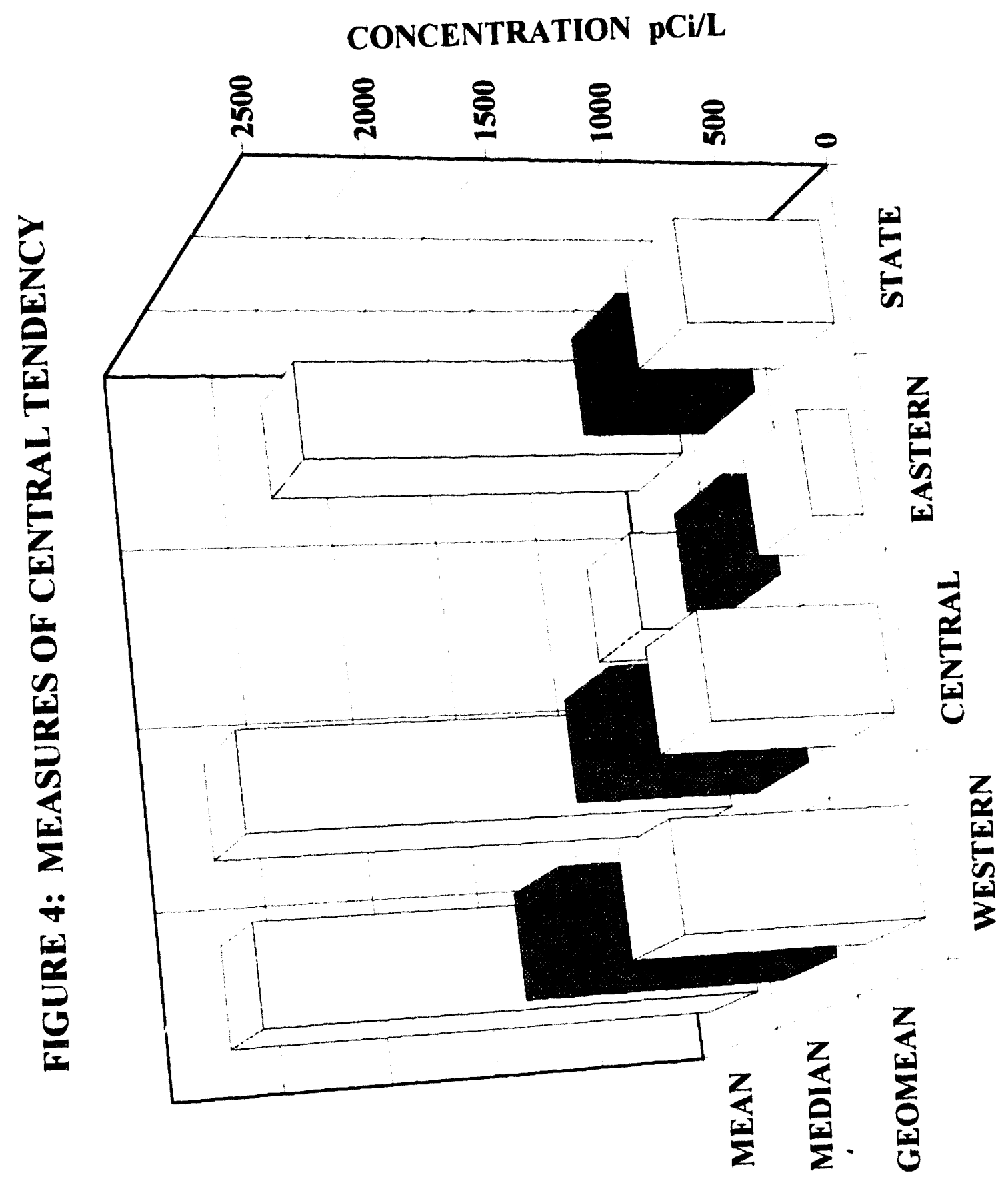


FIGURE 5: PROPORTION OF RADON CONCENTRATIONS EXCEEDING SPECIFIED LEVELS

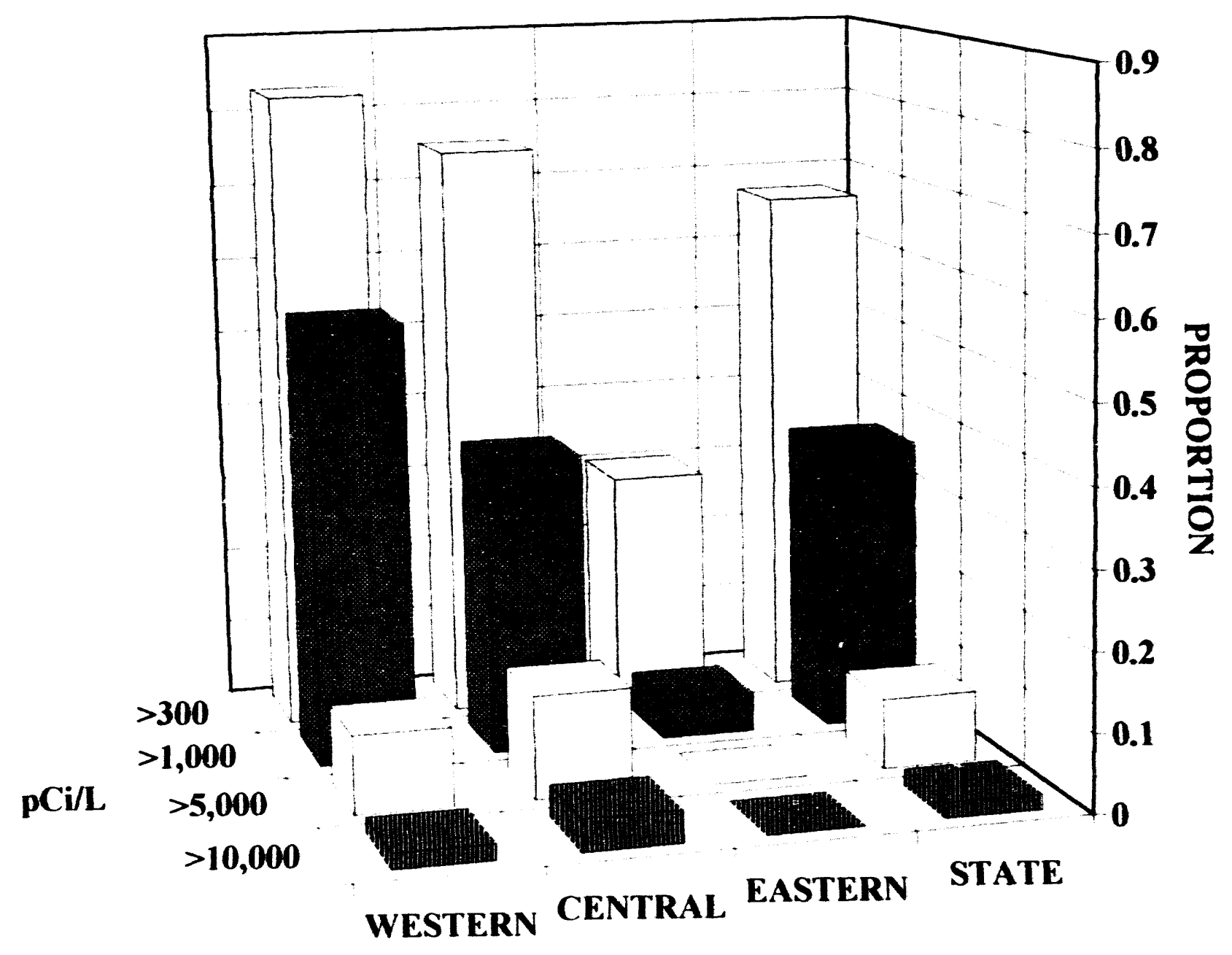


FIGURE 6: N.C. GROUNDWATER RADON LEVELS (0-10,000 pCi/L)

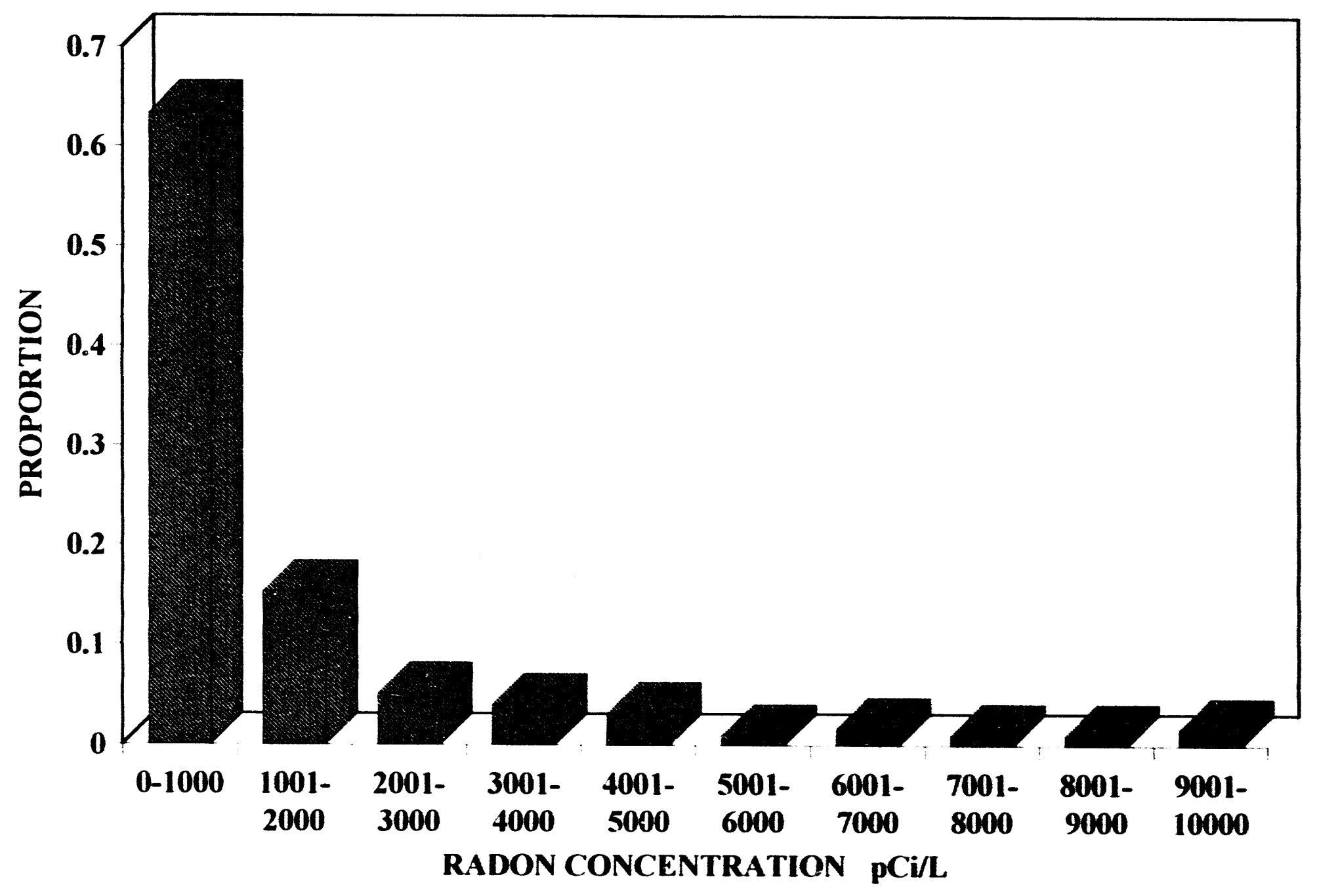


FIGURE 7: NATURAL LOG N.C. GROUNDWATER RADON LEVELS

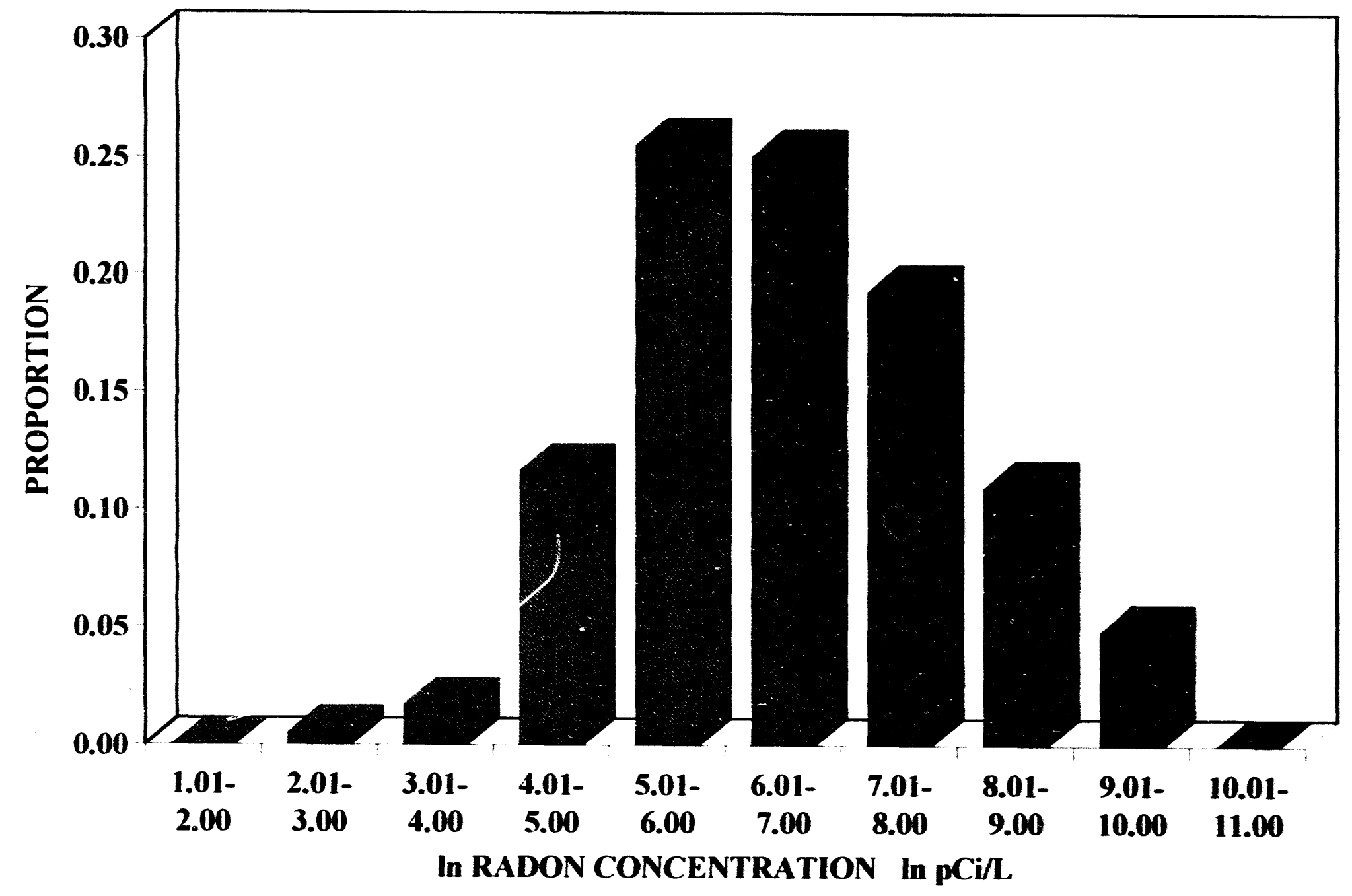




\section{FIGURE 8: DISTRIBUTION OF N. C. GROUNDWATER RADON}

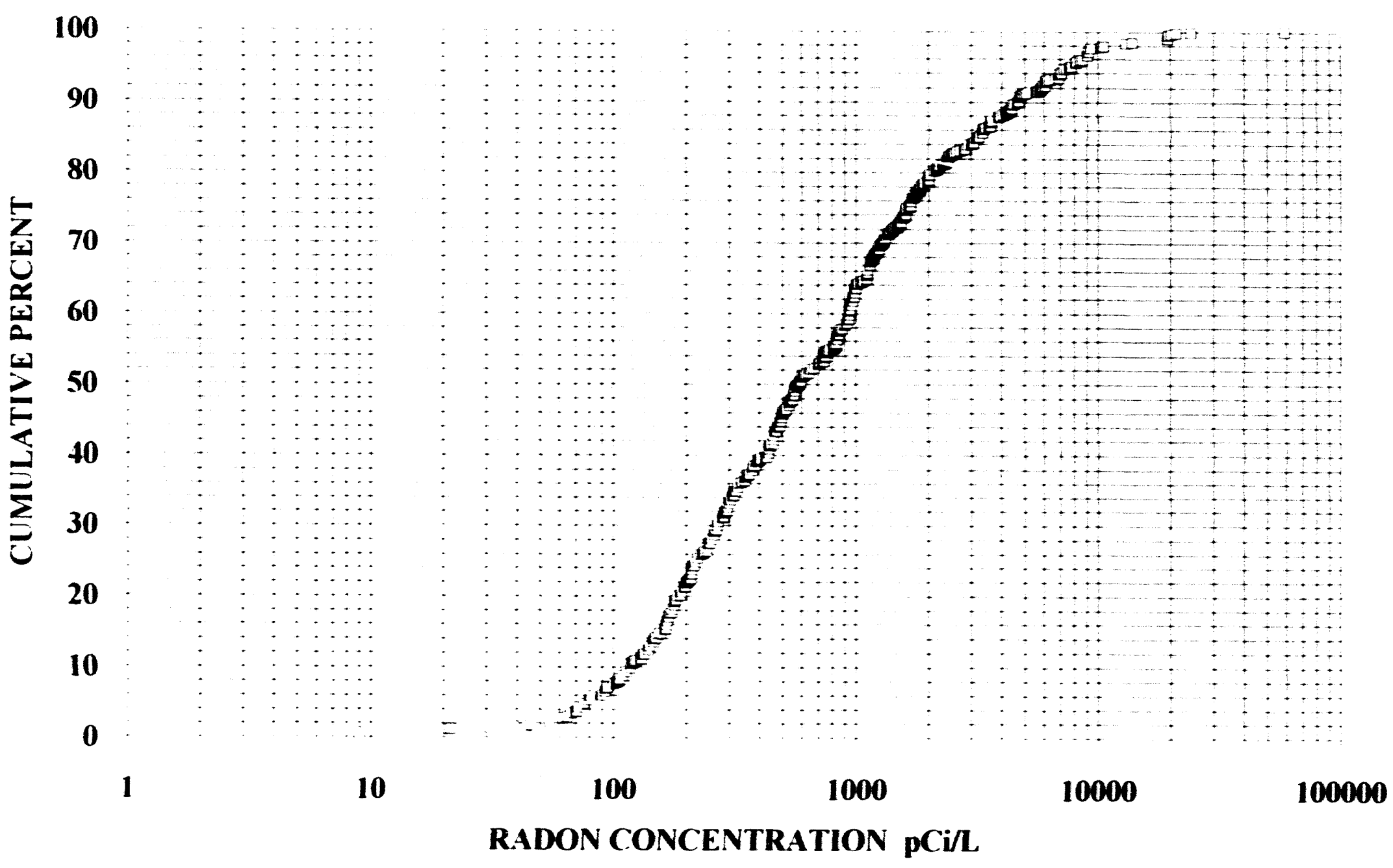


Figures 9 - 11 show regional frequency distributions of groundwater radon concentrations that appear similar in shape to the state wide frequency distribution (Figure 6). A larger number of samples would increase statistical power and probably produce regional frequency distributions which more closely approximate log normal distributions. Figure 12 shows a map of N.C. counties with their number of samples (in parentheses) and mean radon concentrations in $\mathrm{pCi} \mathrm{L}^{-1}$. The highest levels are in the Western and Central regions. Further sampling is needed to gain enough statistical power to get viable mean concentration estimates for the counties. Appendix VI lists the data for the groundwater radon and indoor air radon concentrations.

\section{Analysis of Paired Water Samples}

Of the 400 homes sampled, 364 dual samples were obtained. (Appendix VII contains the concentrations for the individual vials.) All dual samples were analyzed for percent difference, and Figure 12 shows the frequency distribution for the analysis. Over $75 \%$ of the pairs had percent differences of $10 \%$ or less and $90 \%$ had percent differences of $20 \%$ or less. Potential sources of error within paired samples include leakage of radon from one (or both) of the vials and/or overfilling of a vial by the homeowner. Leakage of radon from the vials appeared minimal after several sequential LSC runs of the same samples.

\section{Analysis of Paired Air and Water Data}

The residential water radon data were paired to the corresponding home air radon data yielding 389 pairs of data. (Some indoor measurements were not present in the NC / RTI information.) There are a few negative readings for the indoor radon levels. The negative measurements were included in the analysis to avoid introduction of bias. The scatter plot of air radon concentrations versus water radon concentrations for $\mathrm{NC}$. are shown on Figure 14. Linear regression analysis found a correlation coefficient of 0.00921 , indicating a very weak linear relationship. The regional plots (Figures 15-17) are very similar in appearance to the state wide plot. Without a log axis for the concentration, the data markers produce an unintelligible blot on the scatter plots. 
FIGURE 9: N.C. EASTERN REGION GROUNDWATER RADON LEVELS

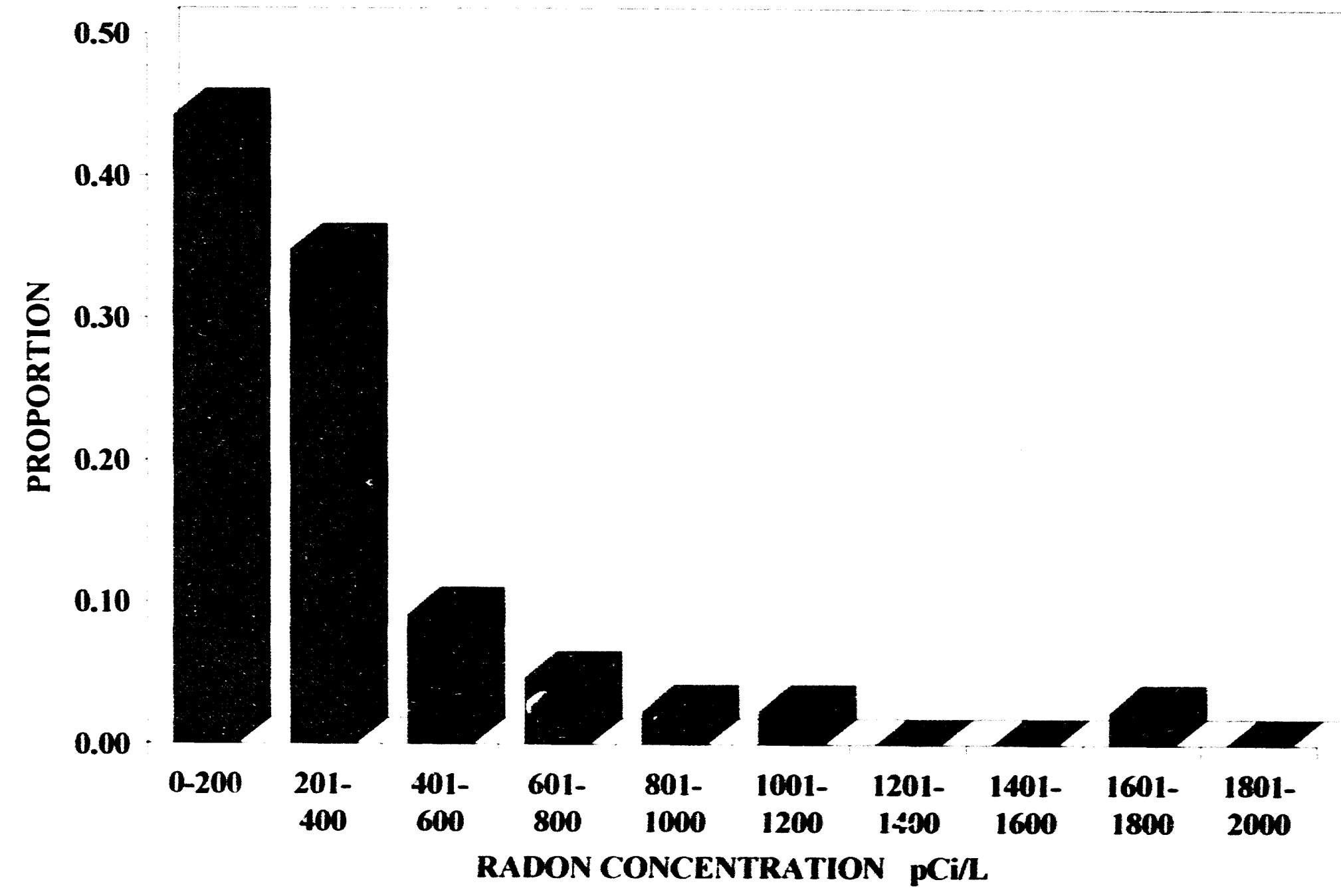


FIGURE 10: N.C. CENTRAL REGION GROUNDWATER RADON

LEVELS (0-10,000 pCi/L)

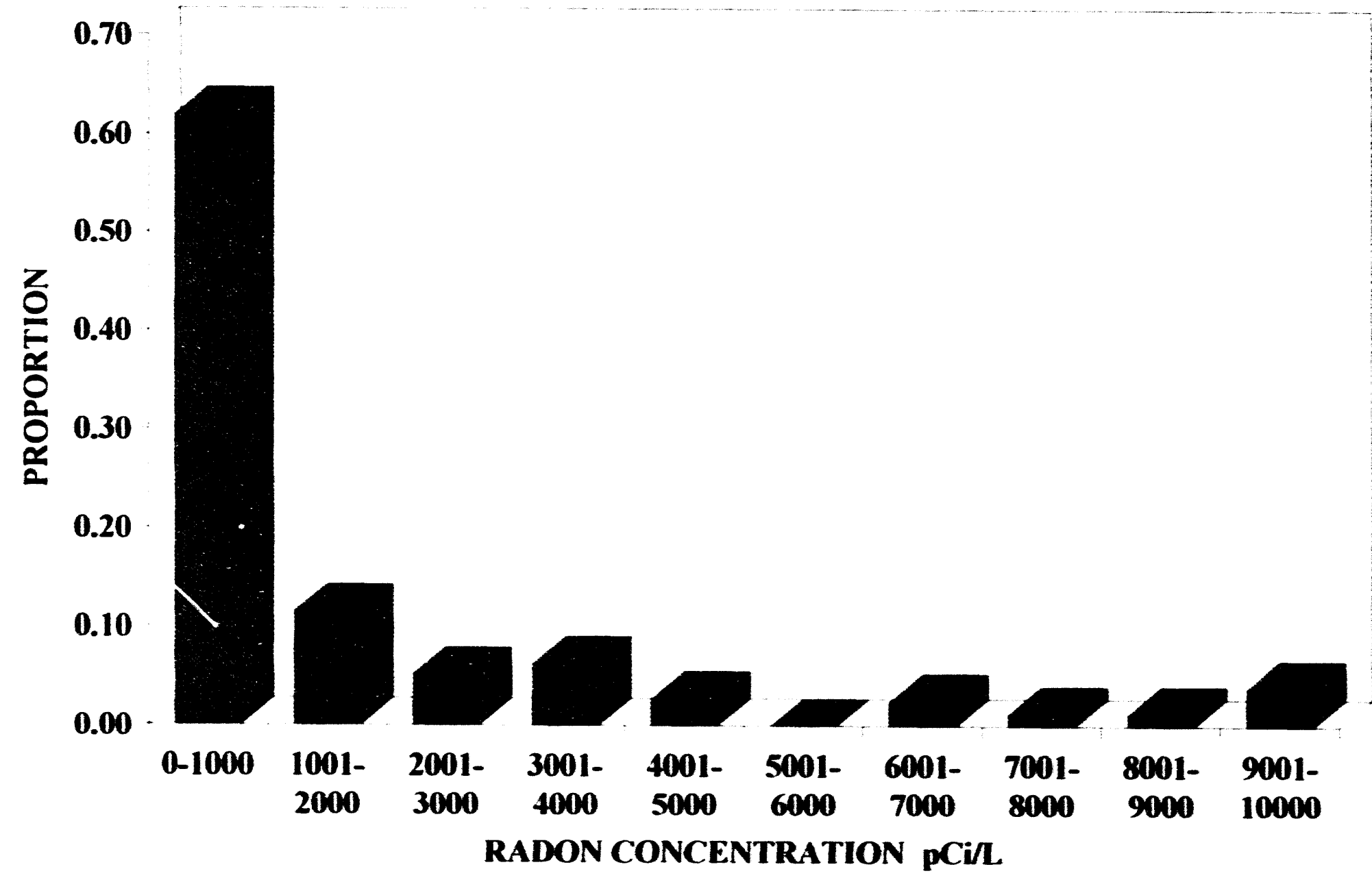


FIGURE 11: N.C. WESTERN REGION GROUNDWATER RADON

LEVELS (0-10,000 pCi/L)

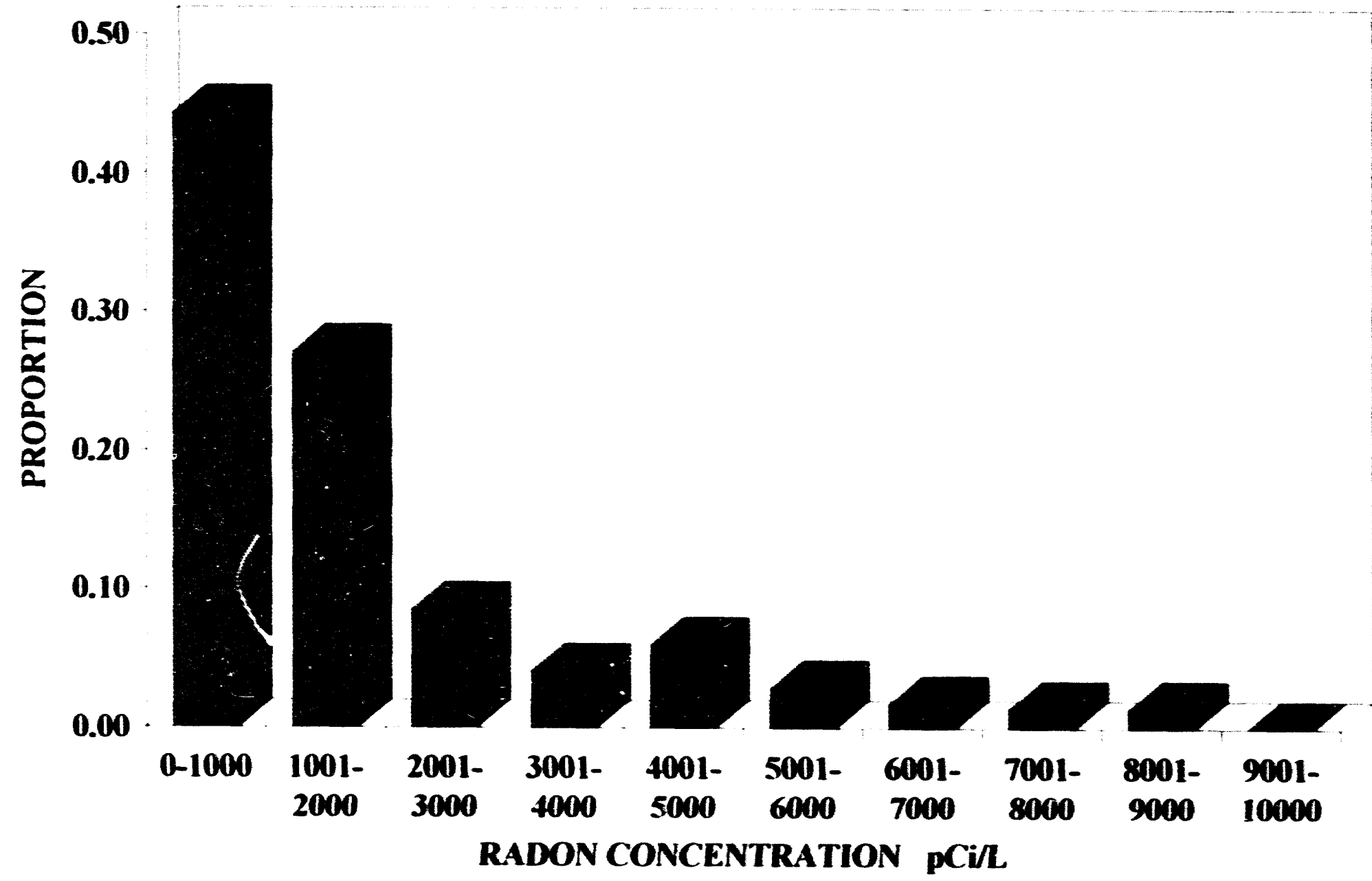




\section{FIGURE 12: NORTH CAROLINA COUNTY MEAN GROUNDWATER RADON}

CONCENTRATIONS

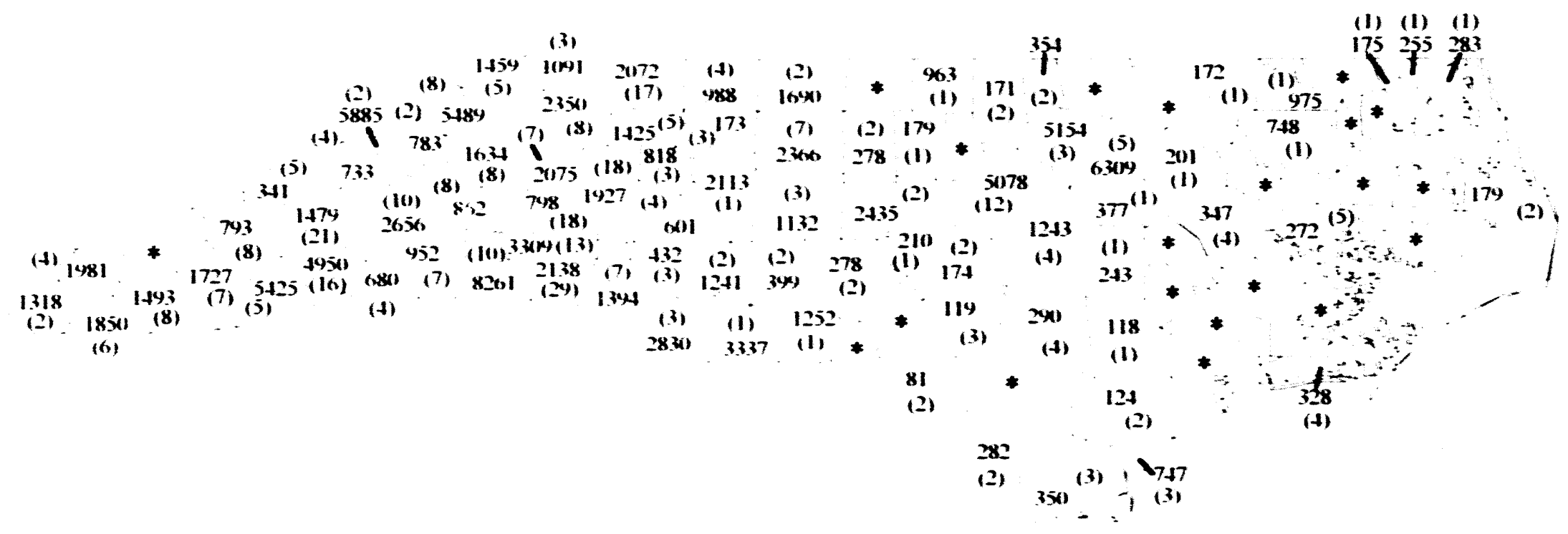

CONCENTRATIONS IN pCi/L

NUMBER OF SAMPLES IN PARENTHESES

NO DATA FOR COUNTY * 


\section{FIGURE 13: DUAL SAMPLES - PAIR PERCENT DIFFERENCES}

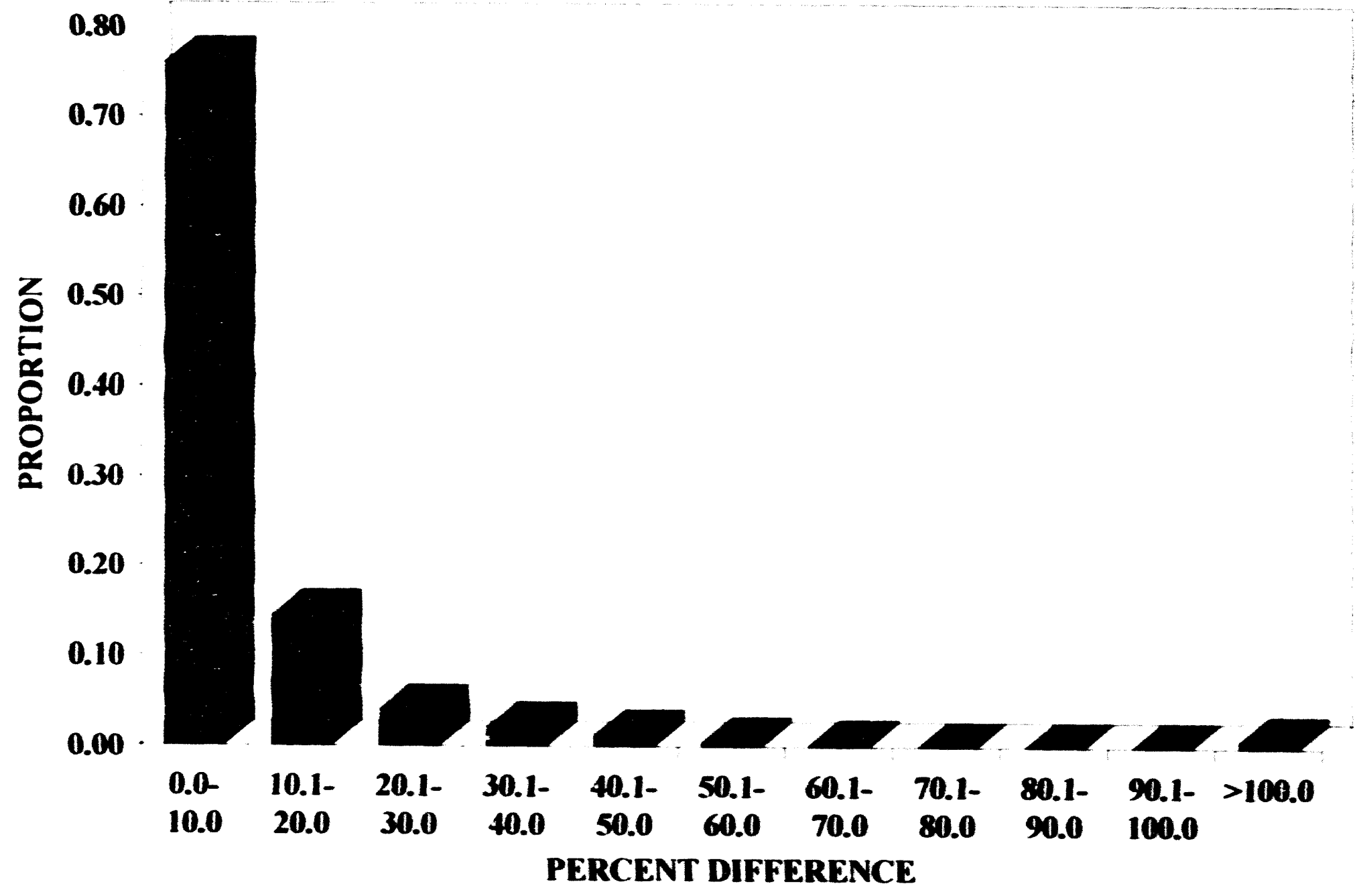


FIGURE 14: N.C. GROUNDWATER RADON CONCENTRATIONS VS. INDOOR RADON CONCENTRATIONS

25

20

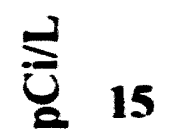

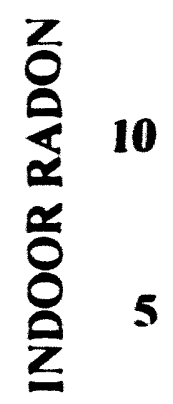

0

$-5$

10

100

1000

10000

100000

GROUNDWATER RADON pCi/L 
FIGURE 15: N.C. EASTERN REGION GROUNDWATER RADON CONCENTRATIONS VS. INDOOR RADON CONCENTRATIONS

5

4

记 3

ż

2

0

$-1$ 
FIGURE 16: N.C. CENTRAL REGION GROUNDWATER RADON CONCENTRATIONS VS. INDGOR RADON CONCENTRATIONS

4

高 3

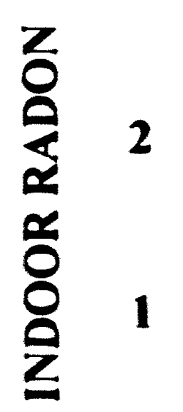

0

$-1$

10

100

1000

10000

100000 
T/!Od NOAYY dG.LVMaNnOy?

00000 I

000 I

$00 I$

0I

$\mathbf{0}$

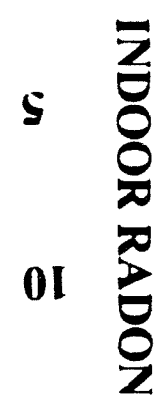

SI ڤุ

$\mathbf{0 z}$

$\mathbf{s \tau}$

SNOILVYILNGDNOD NOAVY XOOANI SA SNOIIVZINGDNOD

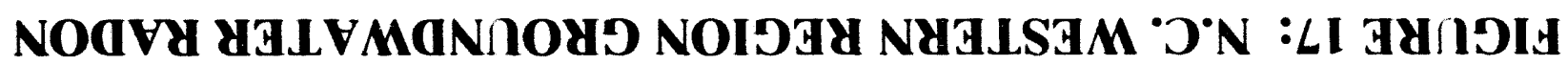




\section{DISCUSSION}

The wells of 400 North Carolina homes were sampled to ascertain the distribution and extent of ${ }^{222} \mathrm{Rn}$ in North Carolina groundwater. Arithmetic and geometric mean concentrations of $1,816 \mathrm{pCi} \mathrm{L}^{-1}$ and $656 \mathrm{pCi} \mathrm{L}^{-1}$ were found for the state. These results indicate that two-thirds of N.C. homes (served by groundwater) exceed the EPA proposed $300 \mathrm{pCi} \mathrm{L}^{-1}$ maximum contaminant level (MCL). Only $2 \%$ of N.C. homes exceeded $10,000 \mathrm{pCi} \mathrm{L}^{-1}$. The distribution of the groundwater data approaches a log normal distribution.

The Eastern region had the lowest concentrations by far. About $30 \%$ of the homes surpassed the $300 \mathrm{pCi} \mathrm{L}^{-1}$ level but none of the samples exceeded $2,000 \mathrm{pCi} \mathrm{L}^{-1}$. The arithmetic and geometric means were $318 \mathrm{pCi} \mathrm{L}^{-1}$ and $230 \mathrm{pCi} \mathrm{L}^{-1}$ respectively. The low radon concentrations are typical of the Eastern region. The coastal plain (Eastern region) is comprised of clastic sediments underlain by metamorphic rocks. Other states on the east coast show similar findings for their coastal plain regions (Michel 1990, Longtin 1990).

About $75 \%$ of the Central region homes exceed the $300 \mathrm{pCi} \mathrm{L}^{-1} \mathrm{MCL}$. The arithmetic mean of $2,252 \mathrm{pCi} \mathrm{L}^{-1}$ is a sharp contrast to the Eastern result. However, the geometric mean is only $794 \mathrm{pCi} \mathrm{L}^{-1}$. All Central region samples were below $20,000 \mathrm{pCi}$ $\mathrm{L}^{-1}$. The arithmetic mean for the Western region is $2,262 \mathrm{pCi} \mathrm{L}^{-1}$. This is almost identical to that of the Central region. However, the geometric mean of $1,189 \mathrm{pCi} \mathrm{L}^{-1}$ is considerably higher than the $794 \mathrm{pCi} \mathrm{L}^{-1}$ result for the Central region. Over $80 \%$ of the homes exceed $300 \mathrm{pCi} \mathrm{L}^{-1}$ for the Western region. The elevated readings for the Central and Western regions are consistent with those of other studies which found elevated air and groundwater radon concentrations in the Mountain and Piedmont areas (Watson et al 1988, Longtin 1990, Sasser and Watson 1978, Dillon et al. 1991).

The highest measured groundwater radon concentrations generally came from the western piedmont and the mountainous areas - this is concordant with the area geology. 
The mountains and piedmont are comprised of crystalline granitic rocks and a variety of complex metamorphic rocks.

Table 2 shows that $4 \%$ of homes in the Central region exceed $10,000 \mathrm{pCi} \mathrm{L}^{-1}$, but only $2 \%$ exceed $10,000 \mathrm{pCi} \mathrm{L}^{-1}$ in the Western region. However, the Western region has a higher median and a higher geometric mean than the Central Region. More intensive sampling of the Central region would increase the statistical power of the analysis and should help identify the similarity (or lack there of) between the statistics of the Western and Central regions. Moreover, further data from the Eastern region would help provide a more complete analysis for the state. Figure 12 indicates a lack of data in many counties. Further studies could also identify potential "hot spots".

Generally, the risk from radon in groundwater is associated with the inhaled dose from the radon emitted to air (USEPA 1991). The EPA proposed MCL of $300 \mathrm{pCi} \mathrm{L}^{-1}$ is primarily based on the contribution of radon from water to indoor air, hence the inhalation pathway. However, the ingestion of radon laden water may contribute to increased risk to the stomach, intestines, and other organs (Crawford-Brown 1990). It is unclear how much risk may be attributed to ingestion, but the pathway should not be ignored.

The number of North Carolinians who live in homes served by groundwater is estimated to be 3.8 million (personal communication with Thomas Dickey, Groundwater Section, N.C. Division of Environmental Management). The state AM and GM of 1,816 $\mathrm{pCi} \mathrm{L}^{-1}$ and $656 \mathrm{pCi} \mathrm{L}^{-1}$ respectively would equate to continuous inhalation exposures of about $0.18 \mathrm{pCi} \mathrm{L}^{-1}$ and $0.07 \mathrm{pCi} \mathrm{L}^{-1}$. These inhalation exposures correspond to estimated lifetime cancer risks of $12 \times 10^{-4}(12$ in 10,000$)$ and $5 \times 10^{-4}(5$ in 10,000) respectively (USEPA 1991). Until further studies of the indoor radon/groundwater radon relationship and radon ingestion pathways are performed, it will be difficult to ascertain the amount of risk associated with a particular concentration of radon in water.

Regarding possible correlation between groundwater radon and indoor radon, no consistent trends were observed. Linear regression analysis showed a very weak linear relationship with a correlation coefficient of 0.00921 . The potential temporal, spatial, and structural variations within a home contribute many unknowns to the analysis. In order to get a more accurate view of the air/water radon relationship, a carefully designed, long term analysis needs to be performed. If homes are known to have high groundwater radon concentrations (i.e., $10,000 \mathrm{pCi} \mathrm{L}^{-1}$ or more), the contribution to indoor air contributions 
may be significant enough to study. Air and water radon measurements would need to be taken at multiple locations within each home. The measurements should be both instantaneous and integrated over time. Home resident living patterns, such as the amount of time home, water use time, and water consumption rate should be analyzed. Air exchange rates would have to be calculated or at least allowed for. The weather (both long and short term) should also be factored into the analysis. Some work has been performed regarding spatial and temporal variations, and great fluctuations in radon measurements have been noted (Steck 1992, Borak, et al. 1989, Cohen 1986, Lawrence, et al. 1992). 


\section{REFERENCES}

Barron, T. EPA proposes waterborne radon MCL standard of $300 \mathrm{pCi} \mathrm{L}^{-1}$. Radon Industry Review, October: 3; 1990.

Bergsten, J. W.; White, S. B.; Hoffman, M. M.; Alexander, B. V.; Potter, F. J.; Williams, W.; Branson, S. L.; Kooyman, C. Support of the state radon assessment program, Final report for year three, Volume 1. Research Triangle Park, NC.: Research Triangle Institute; Research Triangle Institute Report no. RTI / 7804 / 06-03F; 1989.

Borak, T. B.; Woodruff, B.; Toohey, R. E. A survey of winter, summer, and annual average 222-Rn concentrations in family dwellings. Health Phys. 57:465-470; 1989.

Cember, H. Introduction to Health Physics. New York: Pergamon Press; 1988.

Cohen, B. L. A national survey of $222-\mathrm{Rn}$ in U.S. homes and correlating factors. Health Phys. $51: 175-183 ; 1986$.

Crawford-Brown, D. J. Analysis of the health risk from ingested radon. In: Radon, Radium and Uranium in Drinking Water; Chapter 2. Chelsea, MI: Lewis Publishers; 1990.

Davis, R. M.; Watson, J. E. Influence of ${ }^{226} \mathrm{Ra}$ concentrations in surrounding rock on ${ }^{222} \mathrm{Rn}$ concentration in ground water. Health Phys. 58:369-371; 1990

Dillon, M. E.; Carter, G. L.; Arora, R.; Kahn, B. Radon concentrations in ground water of the Georgia piedmont. Health Phys. 60:229-236; 1991.

Flint, R. F.; Skinner, B. J. Physical Geology. New York: John Wiley \& Sons, Inc.; 1977.

Fjeld, R. A.; Jones, M. D.; Bivens, N. Screening survey of indoor ${ }^{222} \mathrm{Rn}$ in South Carolina. Health Phys. 59:217-223; 1990.

Hess, C. T.; Michel, J.; Horton, T. R.; Prichard, H. M.; Coniglio, W. A. The occurrence of radioactivity in public water supplies in the United States. Health Phys. 48:553$586 ; 1985$.

Hess, C. T.; Vietti, M. A.; Lachapelle, E. B.; Guillemette, J. F. Radon transferred from drinking water into house air. In: Radon, Radium and Uranium in Drinking Water; Chapter 5. Chelsea, MI: Lewis Publishers; 1990. 
Horton, T. R. Methods and results of EPA's study of radon in drinking water. Montgomery, AL: Eastern Environmental Radiation Facility; U.S. Environmental Protection Agency report EPA 520/5-83-027; 1983.

Ladrach, K. The occurrence of radon in some North Carolina groundwater supplies Department of Environmental Sciences and Engineering; Master's Technical Report; Chapel Hill, NC: University of North Carolina; 1987.

Lawrence, E. P.; Wanty, R. B.; Nyberg, P. Contribution of ${ }^{222} \mathrm{Rn}$ in domestic water supplies to ${ }^{222} \mathrm{Rn}$ in indoor air in Colorado homes. Health Phys. 62:171-177; 1992.

Longtin, J. Occurence of radionuclides in drinking water, a national study. In: Radon. Radium and Uranium in Drinking Water; Chapter 8. Chelsea, MI: Lewis Publishers; 1990.

Loomis, D. P. An investigation of radon in North Carolina groundwater and its relationship to rock type. Department of Environmental Sciences and Engineering; Master's Thesis; Chapel Hill, NC: University of North Carolina; 1986.

Loomis, D. P. The relationship between water-system size and ${ }^{222} \mathrm{Rn}$ concentration in North Carolina public water supplies. Health Phys. 52:69-71; 1987

Mabry, A. M. Radon-222 concentrations in North Carolina household groundwater supplies. Department of Environmental Sciences and Engineering; Master's Technical Report; Chapel Hill, NC: University of North Carolina; 1992.

Michel, J. Relationship of radium and radon with geological formations. In: Radon. Radium and Uranium in Drinking Water; Chapter 7. Chelsea, MI: Lewis Publishers; 1990.

Mills, W. A. Risk assessment and control management of radon in drinking water. In Radon, Radium and Uranium in Drinking Water; Chapter 3. Chelsea, MI: Lewis Publishers; 1990.

National Council on Radiation Protection and Measurements. Natural background radiation in the United States. Bethesda, MD: NCRP; NCRP Report no. $45 ; 1975$

National Council on Radiation Protection and Measurements. Exposures from the Uranium series with emphasis on radon and its daughters. Bethesda, MD NCRP; NCRP Report no. 77, 1984

National Council on Radiation Protection and Measurements. A handbook of radioactivity measurements procedures, second edition. Bethesda, MD: NCRP; NCRP Report no. 58; 1985. 
Prichard, H. M. The transfer of radon from domestic water to indoor air. Am. Water Works Assoc. J. 79:159-161; 1987.

Prichard, H. M.; Gesell, T. F. Rapid measurements of ${ }^{222}$ Rn concentrations in water with a commercial liquid scintillation counter. Health Phys. 33:557-581; 1977.

Rahlenbeck, S. I.; Stolwijk, J. A.; Cohen, B. L. Indoor ${ }^{222} \mathrm{Rn}$ levels in New York state, North Carolina, and South Carolina. Health Phys. 61:879-884; 1991

Sasser, M. K.; Watson, J. E. An evaluation of the radon concentration in North Carolina ground water supplies. Health Phys. 34:667-671; 1978

Shapiro, J. Radiation Protection: A Guide for Scientists and Physicians. Cambridge Oxford University Press; 1981

Steck, D. J. Spatial and temporal indoor radon variations. Health Phys. 62:351-355; 1992.

U.S. Environmental Protection Agency. A citizen's guide to radon; What it is and what to do about it. Washington, D.C.: Environmental Protection Agency; Report no EPA 86-004; 1986.

U.S. Environmental Protection Agency. Radionuclides in drinking water fact sheet, national primary drinking water regulations for radionuclides - proposed rule. Washington, D.C.: Environmental Protection Agency; Report no. EPA $570 / 9-91$ 700; 1991 .

U.S. Environmental Protection Agency. Reducing your exposure to radon. Washington, D.C. : Environmental Protection Agency; Report no. EPA 570/9-91-600; 1991

Watson, J. E.; Adams, W. C.; Xie, Y.; Fong, S. W ; Newman, H. J. Survey of 222 Rn in North Carolina homes. Health Phys. 55:71-76, 1988

White, S. B.; Bergsten, J. W.; Alexander, B. V.; Rodman, N. F.; Phillips, J. L. Indoor ${ }^{222} \mathrm{Rn}$ concentrations in a probability sample of 43,000 houses across 30 states. Health Phys. 62:41-50; 1992. 


\section{APPENDIX I}

\section{PRINCIPAL DECAYS OF THE URANIUM SERIES}




\section{PRINCIPAL DECAYS OF THE URANIUM SERIES*}

\begin{tabular}{|c|c|c|c|c|}
\hline \multirow{2}{*}{ Nuclide } & \multirow{2}{*}{ Half-Life } & \multicolumn{3}{|c|}{ Energy (MeV) } \\
\hline & & Alpha & Beta & Gamma \\
\hline U.238 & $4.51 \times 10^{9} y$ & $\begin{array}{l}4.198(77 \%) \\
4.149(23 \%) \\
\end{array}$ & & \\
\hline Th-234 & $24.10 \mathrm{~d}$ & & $\begin{array}{l}0.193 \\
0.103 \\
\end{array}$ & $\begin{array}{l}0.092(4 \%) \\
0.063(3 \%) \\
\end{array}$ \\
\hline $\mathrm{Pa}-234 \mathrm{~m}$ & $1.175 \mathrm{~m}$ & & 2.31 & $\begin{array}{l}1.0(1.5 \%) \\
0.76(0.36 \%) \text { I.T }\end{array}$ \\
\hline $\mathrm{Pa}-234$ & $6.66 \mathrm{~h}$ & & 0.5 & \\
\hline U.234 & $2.48 \times 10^{5} \mathrm{y}$ & $\begin{array}{l}4.773(72 \%) \\
4.721(27 \%) \\
\end{array}$ & & \\
\hline Th-230 & $7.7 \times 10^{+} y$ & $\begin{array}{l}4.688(76 \%) \\
4.621(23 \%) \\
\end{array}$ & & $0.068(0.59 \%)$ \\
\hline $\mathrm{Ra}-226$ & $1,622 y$ & $\begin{array}{l}4.785(94 \%) \\
4.602(6 \%) \\
\end{array}$ & & \\
\hline $\mathrm{Rn}-222$ & $3.82 \mathrm{~d}$ & $5.486(100 \%)$ & & \\
\hline Po-218 & $3.05 \mathrm{~m}$ & $6.003(100 \%)$ & & $0.186(3 \%)$ \\
\hline $\mathrm{Pb}-214$ & $26.8 \mathrm{~m}$ & & 0.65 & $\begin{array}{l}0.352(37 \%) \\
0.295(19 \%) \\
0.242(7 \% \%) \\
\end{array}$ \\
\hline $\mathrm{Bi}-214$ & $19.9 \mathrm{~m}$ & $5.05(4 \%)$ & & $\begin{array}{l}1.765(16 \%) \\
1.120(15 \%) \\
0.6093(46 \%) \\
\end{array}$ \\
\hline Po.214 & $1.6 \times 10^{-4} \mathrm{~s}$ & $7.687(100 \%)$ & & \\
\hline $\mathrm{Tl}-210$ & $1.32 \mathrm{~m}$ & & 1.96 & $\begin{array}{l}2.36(100 \%) \\
0.78(100 \%) \\
0.30(100 \%) \\
\end{array}$ \\
\hline $\mathrm{Pb}-210$ & $22.3 y$ & & 0.017 & $0.047(4.5 \%)$ \\
\hline $\mathrm{Bi}-210$ & $5.01 \mathrm{~d}$ & & 1.17 & \\
\hline Po.210 & $138 \mathrm{~d}$ & $5.297(100 \%)$ & & \\
\hline $\mathrm{Pb}-206$ & Stable & & & \\
\hline
\end{tabular}

"Only the most prominent energies are listed. 


\section{APPENDIX II}

\section{MEAN RADON CONCENTRATIONS AND NUMBER}

OF SAMPLES FOR N.C. COUNTIES 


\section{EASTERN REGION}

\begin{tabular}{|l|c|c|}
\hline COUNTY SAMPLED & MEAN (pCI/L) & \# SAMPLES \\
\hline BEAUFORT & 272 & 5 \\
\hline BERTIE & 748 & 1 \\
\hline BRUNSWICK & 350 & 3 \\
\hline CAMDEN & 255 & 1 \\
\hline CARTERET & 328 & 4 \\
\hline COLUMBUS & 282 & 2 \\
\hline CUMBERLAND & 119 & 3 \\
\hline CURRITUCK & 283 & 1 \\
\hline DARE & 179 & 2 \\
\hline DUPLIN & 118 & 1 \\
\hline EDGECOMBE & 201 & 1 \\
\hline HERTFORD & 975 & 1 \\
\hline NEW HANOVER & 747 & 3 \\
\hline NORTHAMPTON & 172 & 1 \\
\hline PASQUOTANK & 175 & 1 \\
\hline PENDER & 124 & 2 \\
\hline PITT & 347 & 4 \\
\hline ROBESON & 81 & 1 \\
\hline SAMPSON & 290 & 4 \\
\hline WAYNE & 243 & 1 \\
\hline WILSON & 377 & 1 \\
\hline
\end{tabular}

\section{NOT SAMPLED}

BLADEN

CHOWAN

CRAVEN

GATES

GREENE

HOKE

HYDE

JONES

LENOIR

MARTIN

ONSLOW

PAMLICO

PERQUIMANS

SCOTLAND

TYRELL

WASHINGTON 


\begin{tabular}{|c|}
\hline NJy8Y \\
\hline$\overline{X \forall A I T \forall R ~}$ \\
\hline WYHYOC \\
\hline $779 \mathrm{MSV}$ \\
\hline a37dWVS LON \\
\hline
\end{tabular}

\begin{tabular}{|c|c|c|}
\hline iा & $8 \angle O S$ & छХXYM \\
\hline$\Sigma$ & $t S \mathcal{E}$ & JJNVA \\
\hline $\bar{\xi}$ & $0\{8 i$ & NOIN \\
\hline $\bar{i}$ & $\mid t=1$ & XTNYLS \\
\hline$F$ & 109 & NYMOY \\
\hline $\bar{i}$ & 0691 & WHHDNIXXJOY \\
\hline I & $2 S Z 1$ & aNOWHDIY \\
\hline$\overline{\mathfrak{E}}$ & हहा। & Hd'TOaNFy \\
\hline$T$ & $\$ 96$ & NOSy $3 \mathrm{~d}$ \\
\hline$T$ & 621 & IDNFYO \\
\hline$\overline{5}$ & $60\{9$ & HSVN \\
\hline $\bar{\tau}$ & $\overline{8 L Z}$ & इYOOWW \\
\hline$\tau$ & $\overline{66 \mathfrak{\varepsilon}}$ & XYGWODLNOW \\
\hline L & tof & D\&กQNGTXXIW \\
\hline T & 012 & 397 \\
\hline $\bar{t}$ & 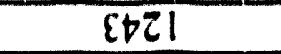 & NOLSNHOI \\
\hline $\bar{Z}$ & $D L 1$ & I.IJNVYH \\
\hline L & $\overline{99 \varepsilon \varepsilon}$ & ayoting \\
\hline $\bar{\tau}$ & 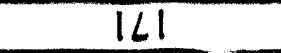 & 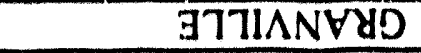 \\
\hline$\varepsilon$ & tSIS & NITXNVYA \\
\hline$\underline{\varepsilon}$ & $\varepsilon \angle 1$ & HLXSYOA \\
\hline T & $\overline{\varepsilon \mid ा \tau}$ & NOSalı $\forall a$ \\
\hline $\bar{\tau}$ & SEDZ & WVHIVHJ \\
\hline $\mathfrak{E}$ & Zहt & 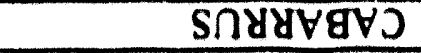 \\
\hline$T$ & $\overline{L E E}$ & NOSNV \\
\hline$\tau$ & $8 L 2$ & GDNVWVTV \\
\hline ST'dWWVS \# & $\left(7 / 1 D^{d}\right)$ NVIW & aG7dWFS AINnOD \\
\hline
\end{tabular}

NOIDGY TVY.LNG? 


\section{WESTERN REGION}

\begin{tabular}{|l|c|c|}
\hline COUNTY SAMPLED & MEAN (pCi/L) & \#SAMPLES \\
\hline ALEXANDER & 2075 & 7 \\
\hline ALLEGHANY & 1091 & 3 \\
\hline ASHE & 1459 & 5 \\
\hline AVERY & 783 & 2 \\
\hline BUNCOMBE & 1479 & 21 \\
\hline BURKE & 862 & 8 \\
\hline CALDWELL & 1634 & 8 \\
\hline CATAWBA & 798 & 18 \\
\hline CHEROKEE & 1318 & 2 \\
\hline CLAY & 1850 & 6 \\
\hline CLEVELAND & 8261 & 10 \\
\hline DAVIE & 818 & 3 \\
\hline GASTON & 2138 & 29 \\
\hline GRAHAM & 1981 & 4 \\
\hline HAYWOOD & 793 & 8 \\
\hline HENDERSON & 4950 & 16 \\
\hline IREDELL & 1927 & 18 \\
\hline JACKSON & 1727 & 7 \\
\hline LINCOLN & 3309 & 13 \\
\hline MACON & 1493 & 8 \\
\hline MADISON & 341 & 5 \\
\hline MCDOWELL & 2656 & 10 \\
\hline MITCHELL & 5885 & 2 \\
\hline POLK & 680 & 4 \\
\hline RUTHERFORD & 952 & 7 \\
\hline STOKES & 988 & 4 \\
\hline SURRY & 2072 & 17 \\
\hline TRANSYLVANIA & 5425 & 5 \\
\hline WATAUGA & 5489 & 8 \\
\hline WILKES & 2350 & 8 \\
\hline YADKIN & 1425 & 5 \\
\hline YANCEY & 733 & 4 \\
\hline
\end{tabular}

\section{NOT SAMPLED}

SWAIN 


\section{APPENDIX III}

HOMEOWNER INSTRUCTION SHEET

FOR OBTAINING WATER SAMPLES 


\section{INSTRUCTIONS}

1. Preparation

- Check the contents of the mailing tube. DO NOT THROW AWAY THE TUBE. You should have the following items:

Reusable mailing tube

Reusable packing material

Return address label and postage

2 glass vials with plastic caps (note: the liquid

in the vials is mineral oil and is not hazardous)

- You also need a pencil or pen and a clock.

- Choose a faucet in your house that does not have an aerator or any other attachments. If this is not possible, then remove the aerator or attachment from a faucet.

2. Taking the samples

- Turn the COLD water on all the way and let it run for five (5) minutes.

- After five (5) minutes turn the water flow down to a slow stream

- Carefully fill each vial to the neck: try not to overfill the vials.

- Immediately put the cap on each vial. Make sure the caps are tight

- Record the date and time below

Date

Month/Day/Year

Time AM PM (circle one)

ID \#

3. Returning the samples

- Carefully wrap the vials in the packing material and place them in the mailing tube

- Place these instructions in the tube (be sure you recorded the date and time above)

- Attach the return label to the tube

- Mail immediately. Any delay will sause the samples to go bad

\footnotetext{
* Note (o the reader. the 11$)$ \# was hilled in hefore mailing the instructions (or each homeowner
} 


\section{APPENDIX IV}

PACKARD TRI-CARB 300

LIQUID SCINTILLATION COUNTER PROGRAM SETTINGS 


\section{LSC Program Settings}

Terminators: $\quad$ Minutes $=50, \quad \%$ Deviation $=2$

Radionuclide $=$ Manual

Windows: ${ }^{*}$
A: $\quad \mathrm{LL}=0 \mathrm{KeV}$
$\mathrm{UL}=2000 \mathrm{KeV}$
B: $\quad L L=5 \mathrm{KeV}$
$\mathrm{UL}=1850 \mathrm{KeV}$
C: $\quad \mathrm{LL}=0 \mathrm{KeV}$
$\mathrm{UL}=$
$5 \mathrm{KeV}$

$\mathrm{QIP}=\mathrm{Yes}$

$\mathrm{AEC}=\mathrm{No}$

$\mathrm{SCR}=\mathrm{A} / \mathrm{B}$

\# Vials / Std $=1, \quad \#$ Vials $/$ Sample $=1, \quad$ \# Counts $/$ Vial $=1$

BKG $=$ Manual: $\quad \mathrm{A}=0, \mathrm{~B}=0, \mathrm{C}=0$

Divide Factor $\mathrm{K}=1$

Data Mode $=\mathrm{CPM}$

* The "B" window is the counting window used for obtaining the gross $\mathrm{cpm}$ for radon concentration calculations. 


\section{APPENDIX V}

CALIBRATION FACTORS AND BACKGROUND

COUNT RATES FOR LSC ANALYSIS 


\section{AVERAGE BACKGROUND AND CALIBRATION FACTORS}

\begin{tabular}{|c|c|c|c|c|c|c|}
\hline DATE & BKG-1 & BKG-2 & AVBKG & CPM-1 & CPM-2 & AVGCF \\
\hline $11-30-90$ & 31.50 & 30.70 & 31.10 & 7205.93 & 9334.62 & 9.91 \\
\hline $12-03-90$ & 31.88 & 32.72 & 32.30 & 7058.39 & 9279.05 & 9.78 \\
\hline $12-06-90$ & 30.52 & 31.34 & 30.93 & 7045.25 & 9081.31 & 9.67 \\
\hline $12-10-90$ & 32.78 & 32.44 & 32.61 & 7170.37 & 9339.42 & 9.89 \\
\hline $12-13-90$ & 29.74 & 29.86 & 29.80 & 7239.85 & 9324.04 & 9.93 \\
\hline $12-19-90$ & 31.26 & 31.02 & 31.14 & 7203.70 & 9321.15 & 9.90 \\
\hline $12-21-90$ & 31.12 & 33.16 & 32.14 & 7462.60 & 9550.98 & 10.20 \\
\hline $1-03-91$ & 31.86 & 32.62 & 32.24 & 7474.61 & 9375.96 & 10.12 \\
\hline $1-10-91$ & 30.14 & 31.20 & 30.67 & 7370.99 & 9536.31 & 10.13 \\
\hline $1-17-91$ & 31.88 & 31.10 & 31.49 & 7305.30 & 9490.29 & 10.06 \\
\hline $1-22-91$ & 29.56 & 30.52 & 30.04 & 7301.50 & 9335.24 & 9.98 \\
\hline $1-25-91$ & 32.76 & 31.26 & 32.01 & 7348.48 & 9508.74 & 10.10 \\
\hline $1-30-91$ & 29.96 & 30.48 & 30.22 & 7058.39 & 9067.29 & 9.87 \\
\hline $1-31-91$ & 31.42 & 29.66 & 30.54 & 7239.55 & 9269.52 & 9.90 \\
\hline 2-03-91 & 30.90 & 30.38 & 30.64 & 7334.85 & 9561.76 & 10.12 \\
\hline $2-04-91$ & 30.86 & 30.20 & 30.53 & 7256.72 & 9420.39 & 9.99 \\
\hline $2-05-91$ & 32.98 & 30.10 & 31.54 & 7383.21 & 9516.67 & 10.13 \\
\hline $2-07-91$ & 31.50 & 28.90 & 30.20 & 7261.19 & 9560.78 & 10.07 \\
\hline $2-09-91$ & 30.82 & 29.62 & 30.22 & 7493.80 & 9431.07 & 10.16 \\
\hline $2-11-91$ & 32.50 & 31.10 & 31.80 & 7252.35 & 9532.35 & 10.05 \\
\hline $2-14-91$ & 31.16 & 30.70 & 30.93 & 7397.71 & 9524.51 & 10.14 \\
\hline $2-15-91$ & 33.00 & 31.64 & 32.32 & 7227.61 & 9191.51 & 9.85 \\
\hline $2-19-91$ & 30.92 & 30.34 & 30.63 & 7355.30 & 9510.78 & 10.11 \\
\hline $2-20-91$ & 30.70 & 30.02 & 30.36 & 7421.37 & 9431.07 & 10.11 \\
\hline $2-22-91$ & 31.08 & 30.30 & 30.69 & 7384.85 & 9375.96 & 10.06 \\
\hline $2-25-91$ & 32.14 & 30.86 & 31.50 & 7423.26 & 9639.60 & 10.22 \\
\hline $2-26-91$ & 31.64 & 31.60 & 31.62 & 7244.03 & 9630.69 & 10.09 \\
\hline $2-27-91$ & 31.88 & 31.46 & 31.67 & 7307.52 & 9406.80 & 10.02 \\
\hline $3-01-91$ & 30.68 & 32.74 & 31.71 & 7255.97 & 9582.35 & 10.08 \\
\hline $3-04 .-91$ & 32.38 & 32.56 & 32.47 & 7231.34 & 9552.94 & 10.04 \\
\hline $3-06-91$ & 32.54 & 31.96 & 32.25 & 7261.94 & 9444.66 & 10.01 \\
\hline $3-10-91$ & 32.28 & 29.78 & 31.03 & 7292.48 & 9427.18 & 10.02 \\
\hline $3-12-91$ & 31.56 & 30.18 & 30.87 & 7280.60 & 9726.00 & 10.17 \\
\hline $3-14-91$ & 31.06 & 29.80 & 30.43 & 7332.58 & 9515.69 & 10.10 \\
\hline $3-15-91$ & 30.58 & 30.26 & 30.42 & 7327.07 & 9385.58 & 10.02 \\
\hline $3-18-91$ & 32.16 & 30.58 & 31.37 & 7351.51 & 9643.56 & 10.17 \\
\hline $3-20-91$ & 30.44 & 30.66 & 30.55 & 7428.24 & 9643.56 & 10.17 \\
\hline $3-22-91$ & 29.80 & 30.32 & 30.06 & 7423.66 & 9670.30 & 10.24 \\
\hline
\end{tabular}


AVERAGE BACKGROUND AND CALIBRATION FACTORS

\begin{tabular}{|c|c|c|c|c|c|c|}
\hline DATE & BKG-1 & BKG-2 & AVBKG & CPM-1 & CPM-2 & AVGCF \\
\hline $3-25-91$ & 30.04 & 29.62 & 29.83 & 7283.58 & 9529.41 & 10.07 \\
\hline $3-27-91$ & 30.80 & 30.68 & 30.74 & 7194.07 & 9291.43 & 9.88 \\
\hline $3-31-91$ & 31.54 & 29.36 & 30.45 & 7358.33 & 9547.06 & 10.13 \\
\hline $4-01-91$ & 30.42 & 30.82 & 30.62 & 7443.08 & 9464.08 & 10.15 \\
\hline $4-02-91$ & 31.10 & 29.46 & 30.28 & 7360.61 & 9527.45 & 10.12 \\
\hline $4-03-91$ & 29.86 & 29.46 & 29.66 & 7324.06 & 9516.63 & 10.09 \\
\hline $4-04-91$ & 31.00 & 28.72 & 29.86 & 7318.04 & 9488.35 & 10.07 \\
\hline $4-05-91$ & 30.96 & 29.06 & 30.01 & 7290.22 & 9360.22 & 9.98 \\
\hline $4-08-91$ & 30.62 & 31.10 & 30.86 & 7310.53 & 9422.33 & 10.03 \\
\hline $4-10-91$ & 32.46 & 30.54 & 31.50 & 7208.21 & 9403.85 & 9.95 \\
\hline $4-12-91$ & 31.56 & 30.98 & 31.27 & 7400.76 & 9592.16 & 10.18 \\
\hline $4-16-91$ & 30.76 & 30.02 & 30.39 & 7318.94 & 9527.18 & 10.09 \\
\hline $4-18-91$ & 31.42 & 29.56 & 30.49 & 7230.60 & 9396.12 & 9.96 \\
\hline $4-22-91$ & 31.62 & 29.82 & 30.72 & 7243.28 & 9565.35 & 10.06 \\
\hline $4-24-91$ & 32.00 & 29.74 & 30.87 & 7272.18 & 9395.19 & 9.99 \\
\hline $4-26-91$ & 29.80 & 29.02 & 29.41 & 7306.77 & 9521.57 & 10.08 \\
\hline $5-03-91$ & 31.16 & 29.26 & 30.21 & 7266.92 & 9245.71 & 9.91 \\
\hline $5-03-91$ & 31.16 & 31.48 & 31.32 & 7496.12 & 9194.34 & 10.04 \\
\hline $5-10-91$ & 29.24 & 29.24 & 29.24 & 7356.06 & 9547.06 & 10.13 \\
\hline $6-06-91$ & 28.42 & 28.54 & 28.48 & 7234.33 & 9466.99 & 10.00 \\
\hline $6-14-91$ & 29.04 & 30.88 & 29.96 & 7290.22 & 9352.96 & 9.98 \\
\hline $7-03-91$ & 28.04 & 29.36 & 28.70 & 7143.38 & 9334.62 & 9.87 \\
\hline $8-04-91$ & 28.62 & 29.72 & 29.17 & 7141.48 & 9348.64 & 9.88 \\
\hline $8-11-91$ & 28.80 & 31.18 & 29.99 & 7217.91 & 9519.74 & 10.02 \\
\hline $8-14-91$ & 28.18 & 30.00 & 29.09 & 7119.12 & 9434.32 & 9.91 \\
\hline
\end{tabular}

DATE .......... Date of sample analysis (month-day-year)

BKG-1 ........ Counts per minute for blank water sample \#1 (cpm)

BKG-2 ......... Counts per minute for blank water sample \#2 (cpm)

AVBKG ....... Average backsround from 2 blank water samples (cpm)

CPM-1 ......... Gross counts per minute for $714 \mathrm{pCi} \mathrm{L}^{-1}$ Radium standard \#1 (cpm)

CPM-2 ........ Gross counts per minute for $952 \mathrm{pCi} \mathrm{L}^{-1}$ Radium standard \#2 (cpm)

AVGCF ....... Average of the 2 Radium standard calibration factors (cpm/pCi) 


\section{APPENDIX VI}

DATA FOR AIR ANI) WATER RADON ANALYSIS 


\begin{tabular}{|c|c|c|c|c|}
\hline REGION & AIR pCi/L & $\mathrm{H} 20 \mathrm{pCl} / \mathrm{L}$ & HOUSE ID & COUNTY \\
\hline$E$ & 0.6 & 71 & NC00609 & BEAUFORT \\
\hline$E$ & & 76 & $\mathrm{NC00561}$ & BEAUFORT \\
\hline$E$ & 0.0 & 93 & NC01491 & BEAUFORT \\
\hline$E$ & 0.1 & 109 & $\mathrm{NC} 01252$ & BEAUFORT \\
\hline E & 0.5 & 1011 & NC00921 & BEAUFORT \\
\hline$E$ & & 748 & NC00722 & BERTIE \\
\hline $\bar{E}$ & 0.5 & 224 & $\mathrm{NC} 00463$ & BRUNSWICK \\
\hline$E$ & 0.0 & 327 & NC00377 & BRUNSWICK \\
\hline$E$ & 0.7 & 498 & $\mathrm{NCO} 0212$ & BRUNSWICK \\
\hline$E$ & 0.0 & 255 & NC01026 & CAMDEN \\
\hline$E$ & 0.2 & 141 & NC00648 & CARTERET \\
\hline$E$ & -0.1 & 197 & $\mathrm{NC00385}$ & CARTERET \\
\hline$E$ & 0.5 & 318 & NC00587 & CARTERET \\
\hline$E$ & 0.0 & 6.57 & $\mathrm{NCO} 1293$ & CARTERET \\
\hline$E$ & 0.7 & 269 & NC01356 & COLUMBUS \\
\hline$E$ & -0.1 & 295 & $\mathrm{NC} 00250$ & COLUMBUS \\
\hline E & 0.5 & 67 & $\mathrm{NCO} 1175$ & CUMBERLAND \\
\hline E & 0.1 & 80 & $\mathrm{NC} 01435$ & CUMBERLAND \\
\hline E & 0.9 & 211 & $\mathrm{NC} 00822$ & CUMBERLAND \\
\hline E & 0.2 & 283 & NC00596 & CURRITUCK \\
\hline$E$ & -0.3 & 168 & NC00883 & DARE \\
\hline$E$ & 0.1 & 191 & $\mathrm{NC} 00741$ & DARE \\
\hline$E$ & 0.4 & 118 & $\mathrm{NCO} 4487$ & DUPLIN \\
\hline$E$ & & 201 & $\mathrm{NC} 00169$ & EDGECOMBE \\
\hline$E$ & 0.8 & 975 & NC00708 & HERTFORD \\
\hline E & 0.3 & 214 & NC00379 & NEW HANOVER \\
\hline$E$ & -0.5 & 312 & $\mathrm{NC} 00172$ & NEW HANOVER \\
\hline$E$ & 0.2 & 1715 & $\mathrm{NC} 00600$ & NEW HANOVER \\
\hline$E$ & 1.2 & 172 & $\mathrm{NC} 01365$ & NORTHAMPTON \\
\hline$E$ & 0.2 & 175 & $\mathrm{NCO0829}$ & PASQUOTANK \\
\hline$E$ & 0.3 & 94 & $\mathrm{NC} 00844$ & PENDER \\
\hline $\mathrm{E}$ & 0.1 & 154 & $\mathrm{NC} 01350$ & PENDER \\
\hline $\mathrm{E}$ & 0.0 & 133 & $\mathrm{NC} 00527$ & PITT \\
\hline$E$ & 4.1 & 166 & NC00740 & PITT \\
\hline$E$ & 0.7 & 534 & NC00643 & PITT \\
\hline$E$ & 0.0 & 558 & $\mathrm{NC} 00233$ & PITT \\
\hline $\mathrm{E}$ & -0.2 & 81 & $\mathrm{NCO} 1415$ & ROBESON \\
\hline $\mathrm{E}$ & 0.3 & 113 & $\mathrm{NCO} 1170$ & SAMPSON \\
\hline$E$ & 1.0 & 249 & NC00695 & SAMPSON \\
\hline E & 0.5 & 263 & $\mathrm{NC} 00282$ & SAMPSON \\
\hline$E$ & 0.8 & 534 & $\mathrm{NCO} 1401$ & SAMPSON \\
\hline
\end{tabular}




\begin{tabular}{|c|c|c|c|c|}
\hline REGION & AIR pCl/L & $\mathrm{H} 20 \mathrm{pCl} / \mathrm{L}$ & HOUSE ID & COUNTY \\
\hline$E$ & 0.2 & 243 & $\mathrm{NCO0270}$ & WAYNE \\
\hline $\mathrm{E}$ & .0 .5 & 377 & NCO1168 & WILSON \\
\hline $\bar{C}$ & $0 . \overline{3}$ & 118 & NC00854 & ALAMANCE \\
\hline $\mathrm{C}$ & 1.1 & 437 & NC00880 & ALAMANCE \\
\hline C & 0.3 & 3337 & NC00166 & ANSON \\
\hline C & & 9 & $\mathrm{NCO} 1374$ & CABARRUS \\
\hline $\bar{C}$ & 0.0 & 270 & $\mathrm{NCO} 1283$ & CABARRUS \\
\hline C & 0.3 & 705 & NC00359 & CABARRUS \\
\hline C & 1.2 & 744 & $\mathrm{NCO} 1450$ & CABARRUS \\
\hline $\mathrm{C}$ & 0.9 & 146 & NC00605 & CHATHAM \\
\hline $\mathrm{C}$ & 0.9 & 4759 & NC00275 & CHATHAM \\
\hline C & 2.0 & 2113 & NC00227 & DAVIDSON \\
\hline C & 21.5 & 62 & $\mathrm{NCO} 1447$ & FORSYTH \\
\hline C & & 100 & $\mathrm{NCO} / 406$ & FORSYTH \\
\hline C & 0.7 & 230 & $\mathrm{NC} 00473$ & FORSYTH \\
\hline$C$ & 3.1 & 301 & NC00196 & FORSYTH \\
\hline C & 0.0 & 2908 & $\mathrm{NC} 01342$ & FRANKLIN \\
\hline $\mathrm{C}$ & 0.8 & 3359 & NC00625 & FRANKLIN \\
\hline C & 0.8 & 9197 & $\mathrm{NCO0604}$ & FRANKLIN \\
\hline C & -0.1 & 55 & NC00583 & GRANVILLE \\
\hline C & 0.4 & 287 & NC00261 & GRANVILLE \\
\hline$C$ & 0.6 & 148 & NCO 1148 & GUILFORD \\
\hline C & 0.4 & 261 & NC00957 & GUILFORD \\
\hline C & 0.3 & 460 & $\mathrm{NCO1407}$ & GUILFORD \\
\hline C & 07 & 477 & $\mathrm{NC} 00914$ & GUILFORD \\
\hline C & 0.4 & 497 & $\mathrm{NCOO} 213$ & GUILFORD \\
\hline C & 0.8 & 1612 & $\mathrm{NCO} 1477$ & GUILFORD \\
\hline C & 2.7 & 13106 & $\mathrm{NCO0206}$ & GUILFORD \\
\hline C & 0.7 & 104 & $\mathrm{NCO} 1464$ & HARNETT \\
\hline C & 0.6 & 184 & $\mathrm{NC} 00808$ & HARNETT \\
\hline C & .0 .2 & 140 & NCO1219 & JOHNSTON \\
\hline$C$ & 0.0 & 169 & $\mathrm{NC} 00554$ & JOHNSTON \\
\hline C & -0.1 & 217 & NC01152 & JOHNSTON \\
\hline $\mathrm{C}$ & 0.1 & 4444 & $\mathrm{NCO} 1360$ & JOHNSTON \\
\hline C & 0.3 & 210 & $\mathrm{NCO} 1257$ & LEE \\
\hline$C$ & 0.1 & 443 & NC01444 & MECKLENBURG \\
\hline $\bar{C}$ & 1.0 & 906 & NC00636 & MECKLENBURG \\
\hline C & 2.0 & 995 & NC00959 & MECKLENBURG \\
\hline C & 0.5 & 997 & $\mathrm{NC} 01154$ & MECKLENBURG \\
\hline C & 0.5 & 1569 & $\mathrm{NC} 00353$ & MECKLENBURG \\
\hline C & 0.9 & 1695 & $\mathrm{NC} 00387$ & MECKLENBURG \\
\hline
\end{tabular}




\begin{tabular}{|c|c|c|c|c|}
\hline REGION & AIR pCi/L & $\mathrm{H} 20 \mathrm{pCl} / \mathrm{L}$ & HOUSE ID & COUNTY \\
\hline C & 0.8 & 3153 & NCOII95 & MECKL.ENBURG \\
\hline C & -0.1 & 328 & NCO1094 & MONTGOMERY \\
\hline $\mathrm{C}$ & 0.3 & 469 & $\mathrm{NC} 00887$ & MONTGOMERY \\
\hline C & 0.0 & 179 & $\mathrm{NCO} 1340$ & MOORE \\
\hline C & 10 & 377 & NC00271 & MOORE \\
\hline C & -0.1 & 859 & $\mathrm{NC} 00507$ & NASH \\
\hline C & 0.7 & 1145 & NC01194 & NASH \\
\hline C & 0.6 & 3910 & $\mathrm{NCO} 1029$ & NASH \\
\hline C & 0.4 & 6075 & NCO 1198 & NASH \\
\hline C & 0.8 & 19558 & $\mathrm{NCOO444}$ & $\mathrm{NASH}$ \\
\hline C & 0.6 & 179 & $\mathrm{NC} 00922$ & ORANGE \\
\hline C & 0.0 & 963 & NCO1329 & PERSON \\
\hline C & 0.5 & 459 & $\mathrm{NCO} 0933$ & RANDOLPH \\
\hline C & & 941 & NC00809 & RANDOLPH \\
\hline C & 1.2 & 1117 & NCO1521 & RANDOLPH \\
\hline $\mathrm{C}$ & 07 & 2012 & $\mathrm{NCOOG23}$ & RANDOLPH \\
\hline$C$ & 0.3 & 1252 & NC00901 & RICHMOND \\
\hline $\mathrm{C}$ & 0.2 & 943 & $\mathrm{NCO} 1353$ & ROCKINGHAM \\
\hline C & 15 & 2438 & $\mathrm{NCO} 0602$ & ROCKINGHAM \\
\hline C & 0.8 & 394 & $\mathrm{NCO} / 404$ & ROWAN \\
\hline C & .02 & 563 & $\mathrm{NC} 00248$ & ROWAN \\
\hline C & .0 .2 & 602 & $\mathrm{NC} 00913$ & ROWAN \\
\hline C & 0.5 & 843 & NCO1220 & ROWAN \\
\hline C & 2.0 & 1148 & NC00909 & STANLY \\
\hline $\mathrm{C}$ & 09 & 1333 & $\mathrm{NC} 006.34$ & STANLY \\
\hline $\mathrm{C}$ & 0.0 & 518 & $\mathrm{NC} 00394$ & UNION \\
\hline C & 0.2 & 983 & $\mathrm{NC} 00162$ & UNION \\
\hline C & 0.0 & 6988 & $\mathrm{NCO} 1310$ & UNION \\
\hline C & 0.6 & 354 & NC00916 & VANCE \\
\hline$C$ & 1.3 & 21 & $\mathrm{NC} 0096.3$ & WAKE \\
\hline C & 0.6 & 436 & NCO0168 & WAKE \\
\hline C & 02 & 570 & $\mathrm{NCO} 1047$ & WAKE \\
\hline C & 0.5 & 853 & $\mathrm{NC} 00223$ & WAKE \\
\hline C & 1.3 & 934 & $\mathrm{NC} 01341$ & WAKE \\
\hline C & 1.4 & 1121 & $\mathrm{NCO} 1177$ & WAKE \\
\hline C & -0.4 & 3615 & NCO1355 & WAKE \\
\hline C & 1.6 & 7265 & $\mathrm{NCO} 1402$ & WAKE \\
\hline$C$ & 1.0 & 8104 & $\mathrm{NC} 00795$ & WAKE \\
\hline $\mathrm{C}$ & & 9119 & NC00897 & WAKE \\
\hline C & 16 & 9391 & $\mathrm{NCO0770}$ & WAKE \\
\hline C & 3.3 & 17451 & $\mathrm{NC} 00254$ & WAKE \\
\hline
\end{tabular}




\begin{tabular}{|c|c|c|c|c|}
\hline REGION & AIR pCl/L. & $\mathrm{H} 20 \mathrm{pCl} / \mathrm{L}$ & HOUSE ID & COUNTY \\
\hline$W$ & 0.8 & 121 & $\mathrm{NC} 01.323$ & ALEXANDER \\
\hline $\bar{W}$ & 33 & 343 & NCO1338 & ALIEXANDER \\
\hline $\bar{W}$ & & 926 & $\mathrm{NCO0320}$ & ALEXANDER \\
\hline$W$ & 07 & 1239 & NC01.307 & ALEXANDER \\
\hline$w$ & 04 & 1621 & $\mathrm{NCO} 1223$ & ALEXANDER \\
\hline $\bar{W}$ & 8.9 & 4680 & NC00716 & ALEXANDER \\
\hline $\bar{W}$ & 1.5 & 5592 & NCO0265 & ALEXANDER \\
\hline$w$ & 0.0 & 953 & NCo0ols & ALLEGHANY \\
\hline $\bar{W}$ & 14 & 1024 & NC00628 & ALLEGHANY \\
\hline W & 18 & 1296 & $N(0) 1430$ & ALILGCIIANY \\
\hline$W$ & 09 & 71 & NCo0s49 & ASHE \\
\hline$W$ & 42 & 106 & $N C 00858$ & ASHE \\
\hline$w$ & 29 & 1777 & $\mathrm{~N}(00209$ & ASHE: \\
\hline$W$ & 135 & 2620 & $\mathrm{NC} 01458$ & ASHE \\
\hline$W$ & 14 & 2721 & $\mathrm{NC}(0) 032$ & ASHE \\
\hline$W$ & 06 & 264 & $N(0) \mid 063$ & AVERY \\
\hline$W$ & 46 & 1302 & $N(0)(18.30$ & AVERY \\
\hline$W$ & 07 & 106 & $N(0) 1071$ & BUNCOMBI: \\
\hline$W$ & 08 & 134 & $\mathrm{~N}(0)+48$ & BUNCOMBE: \\
\hline$w$ & 00 & 175 & $N(0) 1216$ & BINCOMBL: \\
\hline$w$ & 10 & 321 & $N(0) 1358$ & BUNCOMBI: \\
\hline$W$ & 43 & 36.5 & $\mathrm{~N}(0)(0.351$ & BUNCOMBE \\
\hline$w$ & 14 & 458 & $N(0) 1137$ & BUNCOMBE \\
\hline$W$ & 05 & 751 & $N(0) 286$ & BI NC(OMIBI: \\
\hline$W$ & 104 & 8.33 & $N(00) 763$ & BUNC()MIBE: \\
\hline$w$ & 05 & 806 & NCo0295 & BUNCOMBE: \\
\hline$w$ & 10 & 886 & $N(00) 300$ & BUNCOMBE \\
\hline$w$ & 40 & 1186 & $N(0) 1298$ & BUNCOMBBE \\
\hline$W$ & 53 & 1.377 & $N(00729$ & BUNC(OMBL: \\
\hline$W$ & 40 & 1496 & $\mathrm{NC}(0) 274$ & BL NCOMBL: \\
\hline$W$ & 26 & 1506 & NC(00810 & BUNCOMBE: \\
\hline $\bar{W}$ & 09 & 1606 & $N(0) 100)$ & BUNCOMBI: \\
\hline$W$ & 11 & 1783 & $N(0) 420$ & BUNCOMBE \\
\hline$W$ & 11 & 1825 & $N(0) 1418$ & BUNCOMBE: \\
\hline$W$ & 25 & 2183 & $N(00280$ & BUNC()MUE: \\
\hline$W$ & 05 & 2324 & NCo1256 & BUNCOMBE: \\
\hline$W$ & 40 & 3062 & $N(0) 1388$ & BUNCOMBE: \\
\hline$W$ & 36 & 7806 & $\mathrm{~N}(0)(052$ & BU NCOMBE \\
\hline$W$ & 31 & 44 & $\mathrm{NC}(0) 1233$ & BL RKE \\
\hline$W$ & 40 & 131 & $N(00518$ & BURKE: \\
\hline$W$ & 24 & 484 & $N(00.360)$ & BURKE: \\
\hline
\end{tabular}




\begin{tabular}{|c|c|c|c|c|}
\hline REGION & AIR pCl/L & $\mathrm{H} 20 \mathrm{pCl} / \mathrm{L}$ & HOUSE ID & COUNTY \\
\hline W & 28 & 598 & NCO1058 & BURKE \\
\hline W & 0.5 & 677 & NC00398 & BURKE \\
\hline $\bar{W}$ & 2.9 & 1113 & NCO1037 & BURKE \\
\hline $\bar{W}$ & .02 & 1404 & NC00926 & BURKE \\
\hline $\bar{W}$ & 4.1 & 2442 & NC00792 & BURKE \\
\hline $\bar{W}$ & 18 & 286 & $\mathrm{NCO} 1243$ & CALDWELL \\
\hline $\bar{W}$ & 0.9 & 404 & $\mathrm{NCOO430}$ & CALDWELL \\
\hline $\bar{W}$ & 42 & 784 & $\mathrm{NC} 00943$ & CALDWELL \\
\hline$W$ & 12 & 1669 & NC01271 & CALDWELL \\
\hline W & 2.2 & 1855 & NC01019 & CALDWELL \\
\hline $\bar{W}$ & 10 & 1923 & $\mathrm{NC00713}$ & CALDWELL \\
\hline W & & 2555 & $\mathrm{NCO0530}$ & CALDWELL \\
\hline W & 1.4 & 3595 & NC00776 & CALDWELL \\
\hline W & 0.3 & 31 & $\mathrm{NCO} 1492$ & CATAWBA \\
\hline$w$ & 0.4 & 104 & NC01376 & CATAWBA \\
\hline$W$ & 0.1 & 125 & NC00466 & CATAWBA \\
\hline $\mathrm{W}$ & 2.1 & 157 & NC00482 & CATAWBA \\
\hline W & & 209 & NC00774 & CATAWBA \\
\hline W & 0.6 & 216 & NC00985 & CATAWBA \\
\hline W & 10 & 237 & $\mathrm{NCO} 243$ & CATAWBA \\
\hline W & 1.1 & 292 & NC00982 & CATAWBA \\
\hline $\mathrm{W}$ & 0.7 & 361 & $\mathrm{NC} 00580$ & CATAWBA \\
\hline$w$ & 0.8 & 388 & NC00974 & CATAWBA \\
\hline$W$ & 30 & 515 & NC00903 & CATAWBA \\
\hline$W$ & 12 & 591 & $\mathrm{NC} 00967$ & CATAWBA \\
\hline W & 0.5 & 813 & NC00268 & CATAWBA \\
\hline$W$ & 36 & 866 & NC00734 & CATAWBA \\
\hline $\bar{W}$ & 00 & 907 & $\mathrm{NCO0471}$ & CATAWBA \\
\hline$W$ & 23 & 1207 & NC00902 & CATAWBA \\
\hline W & 24 & 1236 & NC00746 & CATAWBA \\
\hline W & 12 & 2828 & $\mathrm{NC} 01345$ & CATAWBA \\
\hline W & 14 & 4089 & $\mathrm{NC} 00305$ & CATAWBA \\
\hline W & 10 & 646 & $\mathrm{NC} 00635$ & CHEROKEE \\
\hline$W$ & 1.3 & 1990 & $\mathrm{NCO} 1392$ & CHEROKEE \\
\hline W & 0.6 & 360 & NCO1333 & CLAY \\
\hline W & 0.7 & 710 & NCO1316 & CLAY \\
\hline W & 1.2 & 1744 & $\mathrm{NCO0504}$ & CLAY \\
\hline W & 5.4 & 1890 & $\mathrm{NCO0814}$ & CLAY \\
\hline $\mathrm{W}$ & 08 & 2298 & $\mathrm{NC} 00535$ & CLAY \\
\hline W & 3.6 & 4095 & $\mathrm{NC} 01172$ & CLAY \\
\hline W & 0.2 & 207 & $\mathrm{NCO0245}$ & CLEVELAND \\
\hline
\end{tabular}




\begin{tabular}{|c|c|c|c|c|}
\hline REGION & AIR pCl/L & $\mathrm{H} 20 \mathrm{pCi} / \mathrm{L}$ & HOUSE ID & COUNTY \\
\hline$W$ & 1.5 & 243 & NC00408 & CLEVELAND \\
\hline$W$ & 13 & 856 & NC00956 & CLEVELAND \\
\hline$W$ & 11 & 1120 & $\mathrm{NC} 00754$ & CLEVELAND \\
\hline$W$ & 2.6 & 1690 & NCO1061 & CLEVELAND \\
\hline$W$ & 0.5 & 1831 & NC00908 & CLEVELAND \\
\hline$W$ & 19 & 4912 & $\mathrm{NCO} 1111$ & CLEVELAND \\
\hline$W$ & 10.7 & 5000 & $\mathrm{NCO} 1253$ & CLEVELAND \\
\hline W & 44 & 7662 & $\mathrm{NCO0461}$ & CLEV'ELAND \\
\hline$W$ & 5.5 & 59088 & $\mathrm{NCOO552}$ & CLEVELAND \\
\hline$W$ & 0.2 & 103 & NCO0270 & DAVIE \\
\hline$W$ & 34 & 496 & NC00936 & DAVIE \\
\hline$W$ & 0.4 & 1854 & $\mathrm{NCO0357}$ & DAVIE \\
\hline$W$ & -1.6 & 21 & NC00696 & GASTON \\
\hline$W$ & 0.1 & 39 & $\mathrm{NCO} 1332$ & GASTON \\
\hline$W$ & 04 & 90 & $\mathrm{NCO} 1135$ & GASTON \\
\hline$W$ & 0.1 & 94 & NC00610 & GASTON \\
\hline$W$ & 38 & 203 & $\mathrm{NC} 01150$ & GASTON \\
\hline$W$ & 04 & 251 & NCO0395 & GASTON \\
\hline$W$ & 12 & 268 & $\mathrm{NCOO437}$ & GASTON \\
\hline$W$ & 11 & 472 & $\mathrm{NCO} 1160$ & GASTON \\
\hline$W$ & 13 & 614 & NC01527 & GASTON \\
\hline$W$ & 05 & 617 & $\mathrm{NCOO419}$ & GASTON \\
\hline$W$ & 17 & 6.30 & NCo0s01 & GASTON \\
\hline$W$ & 01 & 745 & $\mathrm{NCO}(0812$ & GASTON \\
\hline$W$ & 14 & 1164 & $\mathrm{NCO} 1001$ & GASTON \\
\hline$W$ & 44 & 1181 & $\mathrm{NC00509}$ & GASTON \\
\hline$W$ & 06 & 1360 & $\mathrm{NC} 00949$ & GASTON \\
\hline$W$ & 00 & 1422 & $N(0) 1382$ & GASTON \\
\hline$W$ & 04 & 1425 & NCO1.380 & GASTON \\
\hline$W$ & 02 & 1489 & $N(0) 231$ & GASTON \\
\hline$W$ & 28 & 1538 & NCO00869 & GASTON \\
\hline$W$ & 09 & 1787 & $\mathrm{NCO}(01347$ & GASTON \\
\hline$W$ & 09 & 1835 & $\mathrm{NCO} 1324$ & GASTON \\
\hline$W$ & 01 & 1853 & NCo0575 & GASTON \\
\hline$W$ & 12 & 1923 & $\mathrm{NC} 01541$ & GASTON \\
\hline$W$ & 21 & 3628 & $\mathrm{NCO} 0396$ & GASTON \\
\hline$W$ & 13 & 4296 & NCOI496 & GASTON \\
\hline$W$ & 19 & 4830 & $\mathrm{NCOO} 2924$ & GASTON \\
\hline$W$ & 00 & 5850 & $\mathrm{NCO} 1052$ & GASTON \\
\hline$W$ & 13 & 8487 & $\mathrm{NCO} / 452$ & GASTON \\
\hline$W$ & 40 & 1.3872 & $\mathrm{NCO}(0)+13$ & GASTON \\
\hline
\end{tabular}




\begin{tabular}{|c|c|c|c|c|}
\hline REGION & AIR pCi/L & $\mathrm{H} 20 \mathrm{pCl} / \mathrm{L}$ & HOUSE ID & COUNTY \\
\hline W & 0.5 & 1182 & NC00698 & GRAHAM \\
\hline W & .0 .4 & 1191 & $\mathrm{NC} 00178$ & GRAHAM \\
\hline W & 8.8 & 2180 & NC00445 & GRAHAM \\
\hline $\bar{W}$ & 2.2 & 3372 & NC01279 & GRAHAM \\
\hline $\bar{W}$ & -0.2 & 65 & NC01207 & HAYWOOD \\
\hline $\bar{W}$ & 0.8 & 489 & NC00731 & HAYWOOD \\
\hline $\bar{W}$ & 10.5 & 502 & NC00738 & HAYWOOD \\
\hline W & 1.3 & 747 & $\mathrm{NC} 00321$ & HAYWOOD \\
\hline W & 37 & 811 & NC00800 & HAYWOOD \\
\hline W & 0.7 & 940 & NC00550 & HAYWOOD \\
\hline W & 14 & 1189 & $\mathrm{NCO0464}$ & HAYWOOD \\
\hline $\bar{W}$ & 1.6 & 1520 & NC00262 & HAYWOOD \\
\hline $\bar{W}$ & 0.1 & 120 & NC00717 & HENDERSON \\
\hline $\mathrm{W}$ & $1 . \overline{3}$ & 165 & NC00639 & HENDERSON \\
\hline $\bar{W}$ & 0.4 & 766 & NC01086 & HENDERSON \\
\hline W & 1.7 & 1248 & $\mathrm{NCO} 1385$ & HENDERSON \\
\hline W & 3.9 & 1581 & NC00955 & HENDERSON \\
\hline W & 6.8 & 1990 & NC00656 & HENDERSON \\
\hline $\bar{W}$ & 55 & 2516 & NC00777 & HENDERSON \\
\hline $\bar{W}$ & 0.9 & 2629 & NC00893 & HENDERSON \\
\hline W & 3.2 & 3971 & NC01064 & HENDERSON \\
\hline 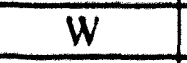 & 1.8 & 4557 & $\mathrm{NCO1461}$ & HENDERSON \\
\hline $\bar{W}$ & 331.8 & 6064 & $\mathrm{NCO} 1274$ & HENDERSON \\
\hline $\bar{W}$ & 15.0 & 6151 & NC00739 & HENDERSON \\
\hline $\bar{W}$ & 33 & 7089 & $\mathrm{NCD0663}$ & HENDERSON \\
\hline $\bar{W}$ & 39 & 8637 & NC00691 & HENDERSON \\
\hline W & 35 & 10587 & $\mathrm{NCO} 1542$ & HENDERSON \\
\hline W & 59 & 21122 & $\mathrm{NC} 00892$ & HENDERSON \\
\hline W & 2.3 & 202 & NCO1305 & IREDELL \\
\hline $\bar{W}$ & 03 & 235 & NC00526 & IREDELL. \\
\hline W & .08 & 304 & NC01308 & IREDELL \\
\hline W & 0.8 & 430 & NC01000 & IREDELL \\
\hline W & 0.3 & 595 & $\mathrm{NC} 00499$ & IREDELL \\
\hline W & 0.6 & 814 & NC00782 & IREDELL \\
\hline $\bar{W}$ & -0.2 & 832 & $\mathrm{NC} 01269$ & IREDELL \\
\hline W & 2.9 & 1077 & NCO1197 & IREDELL \\
\hline W & 0.5 & 1225 & NC00674 & IREDELL \\
\hline W & 1.4 & 1745 & NCO1109 & IREDELL \\
\hline W & 36 & 2003 & $\mathrm{NC} 01368$ & IREDELL \\
\hline $\bar{W}$ & 17 & 2188 & NC00928 & IREDELL \\
\hline $\bar{W}$ & 0.9 & 2374 & $\mathrm{NCO0401}$ & IREDELL \\
\hline
\end{tabular}




\begin{tabular}{|c|c|c|c|c|}
\hline REGION & AIR pCi/L & H2O pCi/L & HOUSE ID & COUNTY \\
\hline W & 2.9 & 3439 & NC00450 & IREDELL \\
\hline W & 2.1 & 4212 & NC00659 & IREDELL \\
\hline W & 0.8 & 4228 & NC01239 & IREDELL \\
\hline W & 0.4 & 4365 & NC01547 & IREDELL \\
\hline W & 3.8 & 4425 & NC01433 & IREDELL \\
\hline W & 3.7 & 150 & NC01400 & JACKSON \\
\hline W & 0.6 & 211 & NC00200 & JACKSON \\
\hline W & 0.8 & 445 & NC00548 & JACKSON \\
\hline W & 0.0 & 1008 & NC01098 & JACKSON \\
\hline W & 0.2 & 3090 & NC00645 & JACKSON \\
\hline W & 5.4 & 3552 & NC00307 & JACKSON \\
\hline W & 3.0 & 3634 & NC01145 & JACKSON \\
\hline W & 0.9 & 46 & NC01004 & LINCOLN \\
\hline W & 0.3 & 105 & NC00224 & LINCOLN \\
\hline W & 0.3 & 293 & NC01129 & LINCOLN \\
\hline W & 0.5 & 315 & NC00888 & LINCOLN \\
\hline W & 5.0 & 379 & NC00226 & LINCOLN \\
\hline W & 0.1 & 1214 & NC01476 & LINCOLN \\
\hline W & 9.3 & 1301 & NC01427 & LINCOLN \\
\hline W & 3.8 & 1364 & NC00361 & LINCOLN \\
\hline W & 1.9 & 1453 & NC01078 & LINCOLN \\
\hline W & 6.1 & 1741 & NC01428 & LINCOLN \\
\hline W & 6.2 & 4815 & NC01199 & LINCOLN \\
\hline W & 0.9 & 5639 & NC01484 & LINCOLN \\
\hline W & 18.8 & 24357 & NC01255 & LINCOLN \\
\hline W & 1.1 & 236 & NC01072 & MACON \\
\hline W & 4.9 & 398 & NC01474 & MACON \\
\hline W & -0.2 & 550 & NC01459 & MACON \\
\hline W & 3.7 & 575 & NC01089 & MACON \\
\hline W & 1.2 & 1167 & NC00404 & MACON \\
\hline W & 2.0 & 1610 & NC01050 & MACON \\
\hline W & 4.3 & 1616 & NC00930 & MACON \\
\hline W & 1.0 & 5789 & NC00208 & MACON \\
\hline W & 1.7 & 130 & NC01228 & MADISON \\
\hline W & 1.2 & 181 & NC00891 & MADISON \\
\hline W & 0.0 & 289 & NC00964 & MADISON \\
\hline W & 1.7 & 511 & NC00454 & MADISON \\
\hline W & 2.0 & 592 & NC01520 & MADISON \\
\hline W & 4.0 & 354 & NC01143 & MCDOWELL \\
\hline W & 2.5 & 1119 & NC00533 & MCDOWELL \\
\hline W & 7.4 & 1228 & NC01317 & MCDOWELL \\
\hline
\end{tabular}




\begin{tabular}{|c|c|c|c|c|}
\hline REGION & AIR pCi/L & H2O pCi/L & HOUSE ID & COUNTY \\
\hline W & 2.7 & 1316 & NC01304 & MCDOWELL \\
\hline W & 1.7 & 1828 & NC01169 & MCDOWELL \\
\hline W & 0.9 & 2231 & NC00712 & MCDOWELL \\
\hline W & 5.3 & 3036 & NC00544 & MCDOWELL \\
\hline W & 2.7 & 3236 & NC00446 & MCDOWELL \\
\hline W & 0.7 & 5897 & NC01296 & MCDOWELL \\
\hline W & 7.0 & 6314 & NC01155 & MCDOWELL \\
\hline W & 1.6 & 4325 & NC01326 & MITCHELL \\
\hline W & 3.5 & 7445 & NC01278 & MITCHELL \\
\hline W & 0.9 & 351 & NC00191 & POLK \\
\hline W & 0.8 & 425 & NC00714 & POLK \\
\hline W & 1.5 & 831 & NC00724 & POLK \\
\hline W & 17.3 & 1113 & NC01375 & POLK \\
\hline W & 1.0 & 189 & NC01112 & RUTHERFORD \\
\hline W & 0.2 & 594 & NC00780 & RUTHERFORD \\
\hline W & 0.8 & 741 & NC00672 & RUTHERFORD \\
\hline W & 0.8 & 831 & NC00941 & RUTHERFORD \\
\hline W & 0.6 & 1052 & NC01437 & RUTHERFORD \\
\hline W & 3.2 & 1523 & NC00388 & RUTHERFORD \\
\hline W & 4.6 & 1734 & NC00409 & RUTHERFORD \\
\hline W & 3.6 & 491 & NC00779 & STOKES \\
\hline W & 1.0 & 510 & NC00154 & STOKES \\
\hline W & 0.2 & 543 & NC00671 & STOKES \\
\hline W & 0.4 & 2408 & NC00264 & STOKES \\
\hline W & 0.4 & 179 & NC00828 & SURRY \\
\hline W & 1.5 & 206 & NC00498 & SURRY \\
\hline W & 0.9 & 337 & NC00783 & SURRY \\
\hline W & 2.3 & 561 & NC00294 & SURRY \\
\hline W & 1.2 & 708 & NC00209 & SURRY \\
\hline W & 6.7 & 953 & NC00997 & SURRY \\
\hline W & & 992 & NC01488 & SURRY \\
\hline W & 1.8 & 1071 & NC01191 & SURRY \\
\hline W & 0.7 & 1603 & NC00217 & SURRY \\
\hline W & 2.8 & 1678 & NC00534 & SURRY \\
\hline W & 3.1 & 1892 & NC01526 & SURRY \\
\hline W & 0.6 & 2007 & NC01371 & SURRY \\
\hline W & 0.1 & 2021 & NC01025 & SURRY \\
\hline W & 2.1 & 2377 & NC00996 & SURRY \\
\hline W & 2.4 & 2409 & NC01066 & SURRY \\
\hline W & 0.3 & 3199 & NC00766 & SURRY \\
\hline W & 0.4 & 6917 & NC00757 & SURRY \\
\hline
\end{tabular}




\begin{tabular}{|c|c|c|c|l|}
\hline REGION & AIR $\mathbf{p C i} / \mathbf{L}$ & $\mathbf{H} 2 \mathbf{0} \mathbf{~ C i / L}$ & HOUSE ID & COUNTY \\
\hline W & 9.5 & 8192 & NC00288 & SURRY \\
\hline W & 2.3 & 2510 & NC00453 & TRANSYLVANIA \\
\hline W & 8.2 & 2846 & NC00415 & TRANSYLVANIA \\
\hline W & 15.4 & 4685 & NC00425 & TRANSYLVANIA \\
\hline W & 5.5 & 6693 & NC00995 & TRANSYLVANIA \\
\hline W & 1.8 & 10391 & NC01146 & TRANSYLVANIA \\
\hline W & 0.5 & 70 & NC00621 & WATAUGA \\
\hline W & 1.3 & 728 & NC01206 & WATAUGA \\
\hline W & 0.4 & 1278 & NC01036 & WATAUGA \\
\hline W & 2.3 & 1416 & NC00977 & WATAUGA \\
\hline W & 14.0 & 5839 & NC01006 & WATAUGA \\
\hline W & 3.1 & 5914 & NC00994 & WATAUGA \\
\hline W & 9.0 & 8483 & NC01093 & WATAUGA \\
\hline W & 7.1 & 20183 & NC01403 & WATAUGA \\
\hline W & 7.3 & 1146 & NC01193 & WILKES \\
\hline W & 1.3 & 1307 & NC01142 & WILKES \\
\hline W & 1.6 & 1317 & NC00953 & WILKES \\
\hline W & 4.0 & 1481 & NC00331 & WILKES \\
\hline W & 1.2 & 2167 & NC01328 & WILKES \\
\hline W & 1.4 & 2189 & NC01159 & WILKES \\
\hline W & 0.2 & 4437 & NC01113 & WILKES \\
\hline W & 1.2 & 4754 & NC00838 & WILKES \\
\hline W & 1.7 & 403 & NC00938 & YADKIN \\
\hline W & 1.9 & 501 & NC00805 & YADKIN \\
\hline W & 0.6 & 548 & NC00251 & YADKIN \\
\hline W & 0.6 & 578 & NC00786 & YADKIN \\
\hline W & 0.8 & 5097 & NC00753 & YADKIN \\
\hline W & 0.1 & 122 & NC01330 & YANCEY \\
\hline W & 0.6 & 198 & NC01513 & YANCEY \\
\hline W & 3.4 & 1283 & NC00381 & YANCEY \\
\hline W & 4.9 & 1329 & NC01018 & YANCEY \\
\hline
\end{tabular}

Concentrations rounded to nearest 10 th $\mathrm{pCi} \mathrm{L}^{-1}$ and nearest $\mathrm{pCi} \mathrm{L}^{-1}$ for air and water respectively. 
APPENDIX VII

DATA FOR PAIRED WATER SAMPLE ANALYSIS 


\begin{tabular}{|c|c|c|c|c|c|c|}
\hline REGION & HOUSE ID & $\mathrm{H} 20 \mathrm{pCi} / \mathrm{L}$ & VIAL 1 & VIAL 2 & ABS DIFF & $\%$ DIFF \\
\hline$E$ & NC00609 & 71 & 81 & 62 & 20 & 27.4 \\
\hline$E$ & NC00561 & 76 & 84 & 68 & 16 & 21.1 \\
\hline$E$ & NC01415 & 81 & 79 & 84 & 5 & 6.6 \\
\hline $\mathrm{E}$ & NC01491 & 93 & 80 & 107 & 27 & 28.7 \\
\hline$E$ & NC00844 & 94 & 89 & 99 & 10 & 10.3 \\
\hline$E$ & $\mathrm{NCO} 1252$ & 109 & 101 & 116 & 15 & 13.7 \\
\hline $\mathrm{E}$ & $\mathrm{NC} 01170$ & 113 & 81 & 146 & 65 & 57.0 \\
\hline$E$ & $\mathrm{NC} 01487$ & 118 & 133 & 103 & 30 & 25.4 \\
\hline$E$ & $\mathrm{NC} 00527$ & 133 & 141 & 124 & 17 & 12.9 \\
\hline$E$ & NC00648 & 141 & 141 & 141 & 0 & 0.3 \\
\hline$E$ & $\mathrm{NC} 01350$ & 154 & 149 & 159 & 10 & 6.5 \\
\hline$E$ & $\mathrm{NC} 00740$ & 166 & 174 & 157 & 16 & 9.8 \\
\hline$E$ & $\mathrm{NC} 00883$ & 168 & 177 & 160 & 17 & 10.3 \\
\hline$E$ & NC01365 & 172 & 174 & 169 & 6 & 3.3 \\
\hline $\mathrm{E}$ & $\mathrm{NC} 00829$ & 175 & 165 & 186 & 20 & 11.4 \\
\hline $\mathrm{E}$ & $\mathrm{NC} 00741$ & 191 & 194 & 187 & 7 & 3.6 \\
\hline $\mathrm{E}$ & NC00385 & 197 & 201 & 192 & 9 & 4.4 \\
\hline$E$ & NC00169 & 201 & 193 & 209 & 16 & 7.9 \\
\hline$E$ & $\mathrm{NC} 00822$ & 211 & 188 & 235 & 47 & 22.4 \\
\hline $\mathrm{E}$ & $\mathrm{NC} 00379$ & 214 & 204 & 224 & 20 & 9.4 \\
\hline$E$ & $\mathrm{NC} 00463$ & 224 & 190 & 257 & 67 & 30.2 \\
\hline$E$ & $\mathrm{NC} 00276$ & 243 & 296 & 191 & 105 & 43.2 \\
\hline$E$ & NC00695 & 249 & 225 & 273 & 48 & 19.3 \\
\hline$E$ & $\mathrm{NC} 01026$ & 255 & 267 & 243 & 24 & 9.5 \\
\hline$E$ & $\mathrm{NC} 00282$ & 263 & 416 & 111 & 304 & 115.6 \\
\hline$E$ & $\mathrm{NC} 01356$ & 269 & 265 & 273 & 8 & 3.2 \\
\hline$E$ & NC00596 & 283 & 291 & 275 & 16 & 5.5 \\
\hline$E$ & $\mathrm{NC} 00250$ & 295 & 293 & 296 & 3 & 0.9 \\
\hline$E$ & $\mathrm{NC} 00172$ & 312 & 301 & 323 & 22 & 6.9 \\
\hline$E$ & NC00587 & 318 & 396 & 240 & 156 & 49.1 \\
\hline$E$ & $\mathrm{NCO} 1168$ & 377 & 393 & 361 & 31 & 8.3 \\
\hline$E$ & $\mathrm{NC} 00643$ & 534 & 537 & 530 & 6 & 1.1 \\
\hline$E$ & NC01401 & 534 & 542 & 527 & 14 & 2.7 \\
\hline$E$ & $\mathrm{NCO} 0233$ & 558 & 587 & 528 & 58 & 10.4 \\
\hline$E$ & $\mathrm{NC} 01293$ & 657 & 676 & 639 & 36 & 5.5 \\
\hline$E$ & NC00708 & 975 & 949 & 1001 & 52 & 5.3 \\
\hline$E$ & $\mathrm{NC} 00921$ & 1011 & 1020 & 1002 & 18 & 1.8 \\
\hline$E$ & $\mathrm{NC} 00600$ & 1715 & 1735 & 1694 & 41 & 2.4 \\
\hline $\mathrm{C}$ & $\mathrm{NC} 01374$ & 9 & 10 & 8 & 1 & 15 \\
\hline $\mathrm{C}$ & NC00963 & 21 & 4 & 37 & 33 & 161.6 \\
\hline C & NC00583 & 55 & 40 & 70 & 30 & 54.9 \\
\hline $\mathrm{C}$ & NC01447 & 62 & 67 & 57 & 10 & 15.6 \\
\hline
\end{tabular}




\begin{tabular}{|c|c|c|c|c|c|c|}
\hline REGION & HOUSE ID & $\mathrm{H} 2 \mathrm{O} \mathrm{pCi} / \mathrm{L}$ & VIAL I & VIAL 2 & ABS DIFF & $\%$ DIFF \\
\hline $\mathrm{C}$ & $\mathrm{NC} 01406$ & 100 & 77 & 123 & 46 & 46.0 \\
\hline $\mathrm{C}$ & $\mathrm{NC} 00854$ & 118 & 142 & 94 & 48 & 40.2 \\
\hline $\mathrm{C}$ & $\mathrm{NC} 01219$ & 140 & 145 & 135 & 10 & 6.8 \\
\hline $\mathrm{C}$ & $\mathrm{NC} 00605$ & 146 & 156 & 137 & 19 & 12.8 \\
\hline $\mathrm{C}$ & NC01464 & 164 & 169 & 158 & 12 & 7.1 \\
\hline $\mathrm{C}$ & $\mathrm{NC} 00554$ & 169 & 167 & 172 & 6 & 3.5 \\
\hline $\mathrm{C}$ & NC00922 & 179 & 178 & 180 & 1 & 0.8 \\
\hline $\mathrm{C}$ & NC00808 & 184 & 174 & 194 & 19 & 10.4 \\
\hline $\mathrm{C}$ & NC01257 & 210 & 236 & 183 & 52 & 25.1 \\
\hline $\mathrm{C}$ & NCO1152 & 217 & 198 & 235 & 36 & 16.7 \\
\hline $\mathrm{C}$ & NC00473 & 230 & 249 & 211 & 38 & 16.3 \\
\hline $\mathrm{C}$ & NC00957 & 261 & 282 & 240 & 41 & 15.8 \\
\hline $\mathrm{C}$ & $\mathrm{NCO} 1283$ & 270 & 280 & 261 & 19 & 7.0 \\
\hline $\mathrm{C}$ & NC00261 & 287 & 355 & 218 & 137 & 47.8 \\
\hline $\mathrm{C}$ & NC00196 & 301 & 268 & 334 & 66 & 21.8 \\
\hline $\mathrm{C}$ & $\mathrm{NCO} 1094$ & 328 & 321 & 335 & 14 & 4.3 \\
\hline $\mathrm{C}$ & NC00916 & 354 & 338 & 370 & 32 & 9.0 \\
\hline$C$ & $\mathrm{NC} 01404$ & 394 & 394 & 395 & 1 & 0.2 \\
\hline $\mathrm{C}$ & NC00168 & 436 & 452 & 420 & 32 & 7.4 \\
\hline $\mathrm{C}$ & NC00880 & 437 & 457 & 417 & 41 & 9.3 \\
\hline $\mathrm{C}$ & NCO 1444 & 443 & 459 & 426 & 33 & 74 \\
\hline $\mathrm{C}$ & NC00933 & 459 & 424 & 494 & 70 & 15.4 \\
\hline $\mathrm{C}$ & $\mathrm{NC} 01407$ & 460 & 515 & 405 & 110 & 24.0 \\
\hline $\mathrm{C}$ & $\mathrm{NC} 00887$ & 469 & 471 & 467 & 4 & 0.9 \\
\hline $\mathrm{C}$ & $\mathrm{NC} 00394$ & 518 & 536 & 500 & 36 & 7.0 \\
\hline $\mathrm{C}$ & NC00248 & 563 & 553 & 574 & 21 & 3.8 \\
\hline $\mathrm{C}$ & NC01047 & 570 & 596 & 544 & 52 & 9.1 \\
\hline $\mathrm{C}$ & $\mathrm{NC} 00913$ & 602 & 587 & 617 & 30 & 5.0 \\
\hline $\mathrm{C}$ & NC00359 & 705 & 740 & 670 & 70 & 9.9 \\
\hline $\mathrm{C}$ & $\mathrm{NC} 00722$ & 748 & 717 & 778 & 61 & 8.2 \\
\hline $\mathrm{C}$ & $\mathrm{NC} 01220$ & 843 & 814 & 872 & 58 & 6.9 \\
\hline $\mathrm{C}$ & $\mathrm{NC} 00223$ & 853 & 861 & 844 & 17 & 2.0 \\
\hline $\mathrm{C}$ & NC00507 & 859 & 894 & 825 & 69 & 8.1 \\
\hline $\mathrm{C}$ & NC00636 & 906 & 892 & 919 & 27 & 3.0 \\
\hline $\mathrm{C}$ & NC01341 & 934 & 938 & 930 & 7 & 0.8 \\
\hline $\mathrm{C}$ & NC00809 & 941 & 919 & 964 & 44 & 4.7 \\
\hline $\mathrm{C}$ & NC00162 & 983 & 964 & 1001 & 38 & 3.8 \\
\hline $\mathrm{C}$ & NC00959 & 995 & 993 & 997 & 4 & 0.4 \\
\hline $\mathrm{C}$ & $\mathrm{NCO} 1154$ & 997 & 1020 & 973 & 48 & 4.8 \\
\hline $\mathrm{C}$ & $\mathrm{NC} 01521$ & 1117 & 1181 & 1053 & 128 & 11.4 \\
\hline $\mathrm{C}$ & $\mathrm{NCO} 1177$ & 1121 & 1140 & 1101 & 39 & 3.5 \\
\hline $\mathrm{C}$ & NC01194 & 1145 & 1179 & 1111 & 68 & 6.0 \\
\hline
\end{tabular}




\begin{tabular}{|c|c|c|c|c|c|c|}
\hline REGION & HOUSE ID & $\mathrm{H} 20 \mathrm{pCi} / \mathrm{L}$ & VIAL 1 & VIAL 2 & ABS DIFF & $\%$ DIFF \\
\hline $\mathrm{C}$ & NC00909 & 1148 & 1133 & 1163 & 30 & 2.6 \\
\hline C & NC00901 & 1252 & 1252 & 1253 & 2 & 0.1 \\
\hline $\mathrm{C}$ & NC00634 & 1333 & 1368 & 1297 & 71 & 5.3 \\
\hline $\mathrm{C}$ & $\mathrm{NCO0353}$ & 1569 & 1568 & 1571 & 2 & 0.2 \\
\hline $\mathrm{C}$ & $\mathrm{NC} 01477$ & 1612 & 1510 & 1715 & 205 & 12.7 \\
\hline $\mathrm{C}$ & NC00387 & 1695 & 1728 & 1663 & 65 & 3.9 \\
\hline $\mathrm{C}$ & NC00623 & 2012 & 2039 & 1986 & 53 & 2.6 \\
\hline $\mathrm{C}$ & $\mathrm{NC00227}$ & 2113 & 2109 & 2117 & 8 & 0.4 \\
\hline $\mathrm{C}$ & $\mathrm{NC} 00602$ & 2438 & 2465 & 2410 & 55 & 2.2 \\
\hline $\mathrm{C}$ & $\mathrm{NC} 01342$ & 2908 & 2937 & 2879 & 58 & 2.0 \\
\hline $\mathrm{C}$ & NC01195 & 3153 & 3106 & 3201 & 94 & 3.0 \\
\hline $\mathrm{C}$ & NC00166 & 3337 & 3278 & 3396 & 118 & 3.5 \\
\hline $\mathrm{C}$ & NC00625 & 3359 & 3358 & 3360 & 2 & 0.1 \\
\hline $\mathrm{C}$ & NC01355 & 3615 & 3633 & 3598 & 34 & 0.9 \\
\hline $\mathrm{C}$ & $\mathrm{NC} 01029$ & 3910 & 3910 & 3909 & 1 & 0.0 \\
\hline $\mathrm{C}$ & $\mathrm{NC} 00275$ & 4759 & 4795 & 4723 & 72 & 1.5 \\
\hline $\mathrm{C}$ & NC01198 & 6075 & 6138 & 6013 & 125 & 2.1 \\
\hline $\mathrm{C}$ & $\mathrm{NC} 01310$ & 6988 & 6994 & 6982 & 11 & 0.2 \\
\hline $\mathrm{C}$ & $\mathrm{NC01402}$ & 7265 & 7182 & 7349 & 167 & 2.3 \\
\hline $\mathrm{C}$ & $\mathrm{NC} 00795$ & 8164 & 8325 & 8003 & 322 & 3.9 \\
\hline C & NC00897 & 9119 & 9007 & 9231 & 224 & 2.5 \\
\hline $\mathrm{C}$ & $\mathrm{NC} 00770$ & 9391 & 9352 & 9429 & 77 & 0.8 \\
\hline $\mathrm{C}$ & $\mathrm{NC00206}$ & 13106 & 12937 & 13276 & 339 & 2.6 \\
\hline C & $\mathrm{NC} 00254$ & 19451 & 19450 & 19453 & 3 & 0.0 \\
\hline $\mathrm{C}$ & $\mathrm{NC} 00444$ & 19558 & 19664 & 19452 & 212 & 1.1 \\
\hline W & $\mathrm{NCOC} 696$ & 21 & 22 & 21 & 1 & 5.4 \\
\hline$W$ & $\mathrm{NCO} 1332$ & 39 & 52 & 20 & 26 & 65.8 \\
\hline$W$ & $\mathrm{NCO} 1004$ & 46 & 53 & 40 & 13 & 284 \\
\hline $\mathrm{W}$ & $\mathrm{NC} 01207$ & 65 & 63 & 67 & 4 & 0.7 \\
\hline$W$ & $\mathrm{NC00621}$ & 70 & 68 & 73 & 5 & 7.3 \\
\hline $\mathrm{W}$ & $\mathrm{NC} 00549$ & 71 & 79 & 63 & 16 & 222 \\
\hline$W$ & $\mathrm{NC} 01135$ & 90 & 92 & 88 & 3 & 38 \\
\hline W & $\mathrm{NC} 00610$ & 94 & 98 & 90 & 8 & 89 \\
\hline $\mathrm{W}$ & NC00270 & 103 & 97 & 109 & 12 & 11.6 \\
\hline W & NC01376 & 104 & 99 & 110 & 11 & 10.3 \\
\hline$W$ & $\mathrm{NCO} 0224$ & 105 & 125 & 85 & 40 & 37.9 \\
\hline$W$ & NC00858 & 106 & 100 & 111 & 11 & 10.1 \\
\hline$W$ & NC01071 & 106 & 123 & 89 & 34 & 316 \\
\hline$W$ & $\mathrm{NC} 00717$ & 120 & 128 & 113 & 15 & 124 \\
\hline$W$ & $\mathrm{NC} 01323$ & 121 & 142 & 101 & 41 & 34.0 \\
\hline$W$ & NC00466 & 125 & 120 & 130 & 10 & 82 \\
\hline $\mathrm{W}$ & $\mathrm{NCO} 1228$ & 130 & 145 & 115 & 29 & 22.5 \\
\hline
\end{tabular}




\begin{tabular}{|c|c|c|c|c|c|c|}
\hline REGION & HOUSE ID & $\mathrm{H} 20 \mathrm{pCi} / \mathrm{L}$ & VIAL 1 & VIAL 2 & ABS DIFF & $\%$ DIFF \\
\hline W & NCO0518 & 131 & 157 & 105 & 52 & 396 \\
\hline$W$ & NCO0448 & 134 & 152 & 117 & 35 & 260 \\
\hline$W$ & NC00482 & 157 & 150 & 164 & 14 & 9.0 \\
\hline W & $\mathrm{NC} 01216$ & 175 & 161 & 189 & 29 & 16.4 \\
\hline$W$ & NC00828 & 179 & 187 & 172 & 15 & 8.3 \\
\hline W & NC00891 & 181 & 190 & 171 & 19 & 10.8 \\
\hline$W$ & $\mathrm{NC} 01112$ & 189 & 176 & 201 & 25 & 13.3 \\
\hline W & $\mathrm{NC} 01513$ & 198 & 192 & 204 & 11 & 5.6 \\
\hline$W$ & $\mathrm{NCO} 1305$ & 202 & 193 & 210 & 17 & 8.5 \\
\hline$W$ & NCO1150 & 203 & 241 & 165 & 76 & 37.4 \\
\hline$W$ & NC00498 & 206 & 208 & 205 & 3 & 1.6 \\
\hline$W$ & $\mathrm{NCO0245}$ & 207 & 241 & 172 & 69 & 33.6 \\
\hline$W$ & NCO0774 & 209 & 207 & 210 & 3 & 1.4 \\
\hline$W$ & NC00200 & 211 & 207 & 215 & 8 & 3.7 \\
\hline W & NC00985 & 216 & 213 & 218 & 4 & 2.1 \\
\hline$W$ & NC00526 & 235 & 273 & 197 & 76 & 32.2 \\
\hline W & $\mathrm{NCO} 1072$ & 236 & 203 & 268 & 65 & 27.6 \\
\hline$W$ & $\mathrm{NCO} 0243$ & 237 & 247 & 228 & 19 & 8.2 \\
\hline W & NC00408 & 243 & 236 & 251 & 15 & 6.3 \\
\hline W & NC00395 & 251 & 240 & 263 & 23 & 9.2 \\
\hline$W$ & NC01063 & 264 & 280 & 247 & 33 & 12.5 \\
\hline$W$ & $\mathrm{NCO} 1243$ & 286 & 272 & 300 & 28 & 97 \\
\hline$W$ & NC00964 & 289 & 279 & 299 & 20 & 0.8 \\
\hline$W$ & NC00982 & 292 & 280 & 303 & 23 & 8.0 \\
\hline$W$ & $\mathrm{NCO} 1129$ & 293 & 297 & 288 & 9 & 32 \\
\hline$W$ & NCO1308 & 304 & 332 & 276 & 56 & 183 \\
\hline W & NC.00888 & 315 & 312 & 317 & 5 & 1.6 \\
\hline W & NCOI358 & 321 & 299 & 343 & 44 & 137 \\
\hline$W$ & NC00783 & 337 & 343 & 330 & 12 & 3.7 \\
\hline W & $\mathrm{NCO} 1338$ & 343 & 320 & 367 & 47 & 13.6 \\
\hline$W$ & $\mathrm{NCO0191}$ & 351 & 360 & 341 & 19 & 5.5 \\
\hline$W$ & $\mathrm{NC} 01143$ & 354 & 347 & 361 & 14 & 4.1 \\
\hline$W$ & $\mathrm{NCO} 1333$ & 360 & 371 & 349 & 22 & 0.0 \\
\hline$W$ & NCO0580 & 361 & 407 & 315 & 91 & 25.3 \\
\hline W & $\mathrm{NCO0351}$ & 365 & 354 & 377 & 23 & 6.3 \\
\hline W & $\mathrm{NCO0226}$ & 379 & 356 & 402 & 46 & 12.2 \\
\hline W & $\mathrm{NC} 00974$ & 388 & 385 & 391 & 6 & 1.6 \\
\hline$W$ & $\mathrm{NC} 01474$ & 398 & 396 & 400 & 4 & 0.9 \\
\hline$W$ & $\mathrm{NC} 00938$ & 403 & 406 & 401 & 6 & 1.4 \\
\hline$W$ & $\mathrm{NC} 00430$ & 404 & 403 & 405 & 2 & 0.4 \\
\hline$W$ & $\mathrm{NC} 00714$ & 425 & 416 & 435 & 19 & 4.5 \\
\hline$W$ & $\mathrm{NCO} 1000$ & 430 & 409 & 452 & 43 & 100 \\
\hline
\end{tabular}




\begin{tabular}{|c|c|c|c|c|c|c|}
\hline REGION & HOUSE ID & $\mathrm{H} 2 \mathrm{O} \mathrm{pCl} / \mathrm{L}$ & VIAL I & VIAL 2 & ABS DIFF & $\%$ DIFF \\
\hline$W$ & NC00548 & 445 & 428 & 463 & 35 & 79 \\
\hline$W$ & $\mathrm{NCO} 1137$ & 458 & 480 & 436 & 44 & 9.6 \\
\hline$W$ & NC01160 & 472 & 504 & 441 & 63 & 134 \\
\hline$W$ & NC00360 & 484 & 454 & 514 & 60 & 12.3 \\
\hline$W$ & NC00731 & 489 & 498 & 480 & 18 & 38 \\
\hline$W$ & NC00779 & 491 & 494 & 488 & 6 & 1.1 \\
\hline$W$ & NC00936 & 496 & 557 & 435 & 123 & 247 \\
\hline$W$ & NC00805 & 501 & 517 & 485 & 32 & 6.4 \\
\hline W & NC00738 & 502 & 503 & 501 & 2 & 0.5 \\
\hline$W$ & $\mathrm{NC} 00154$ & 510 & 486 & 535 & 50 & 9.7 \\
\hline$W$ & NC00454 & 511 & 516 & 507 & 9 & 18 \\
\hline$W$ & NC00671 & 543 & 568 & 518 & 50 & 9.2 \\
\hline$W$ & $\mathrm{NC} 00251$ & 548 & 537 & 558 & 21 & 3.8 \\
\hline$W$ & $\mathrm{NCO} 1459$ & 550 & 574 & 526 & 48 & 8.7 \\
\hline W & NC00294 & 561 & 513 & 609 & 96 & 17.0 \\
\hline$W$ & NC01089 & 575 & 538 & 611 & 73 & 128 \\
\hline$W$ & NC00786 & 578 & 598 & 558 & 40 & 7.0 \\
\hline$W$ & NC00967 & 591 & 562 & 620 & 58 & 99 \\
\hline$W$ & NC00499 & 595 & 634 & 555 & 79 & 132 \\
\hline$W$ & NC01058 & 598 & 554 & 643 & 88 & 148 \\
\hline$W$ & $\mathrm{NCO} 1527$ & 614 & 651 & 577 & 74 & 120 \\
\hline$W$ & $\mathrm{NC} 00501$ & 630 & 594 & 666 & 73. & 11.5 \\
\hline$W$ & $\mathrm{NC} 00635$ & 646 & 590 & 702 & 112 & 17.3 \\
\hline W & NC00398 & 677 & 681 & 673 & 9 & 1.3 \\
\hline$W$ & NC00209 & 708 & 735 & 682 & 54 & 7.6 \\
\hline W & $\mathrm{NC} 01316$ & 710 & 703 & 718 & 15 & 2.1 \\
\hline$W$ & $\mathrm{NCO} 1206$ & 728 & 745 & 711 & 33 & 46 \\
\hline$W$ & NC00672 & 741 & 762 & 721 & 41 & 50 \\
\hline$W$ & $\mathrm{NC} 00812$ & 745 & 755 & 735 & 20 & 2.6 \\
\hline W & $\mathrm{NC} 00321$ & 747 & 754 & 740 & 14 & 1.8 \\
\hline W & NC00286 & 759 & 755 & 762 & 6 & 0.8 \\
\hline $\mathrm{W}$ & NC01086 & 766 & 765 & 767 & 2 & 0.3 \\
\hline W & NC00943 & 784 & 812 & 756 & 57 & 72 \\
\hline$W$ & NC00800 & 811 & 812 & 811 & 0 & 0.1 \\
\hline$W$ & $\mathrm{NCO0268}$ & 813 & 784 & 842 & 58 & 7.1 \\
\hline$W$ & NC00782 & 814 & 808 & 819 & 11 & 1.4 \\
\hline$W$ & NC00724 & 831 & 837 & 825 & 11 & 1.4 \\
\hline$W$ & NC.00941 & 831 & 813 & 848 & 35 & 4.2 \\
\hline$W$ & $\mathrm{NC} 01269$ & 832 & 823 & 841 & 18 & 2.2 \\
\hline W & $\mathrm{NC} 00763$ & 833 & 783 & 882 & 100 & 12.0 \\
\hline W & $\mathrm{NC} 00956$ & 856 & 810 & 902 & 92 & 10.7 \\
\hline W & $\mathrm{NCO0734}$ & 866 & 849 & 883 & 34 & 3.9 \\
\hline
\end{tabular}




\begin{tabular}{|c|c|c|c|c|c|c|}
\hline REGION & HOUSE ID & $\mathrm{H} 20 \mathrm{pCl} / \mathrm{L}$ & VIAL I & VIAL 2 & ABS DIFF & $\%$ DIFF \\
\hline$W$ & $\mathrm{NCO0295}$ & 866 & 840 & 892 & 52 & 6.0 \\
\hline$W$ & NC00390 & 886 & 900 & 872 & 27 & 3.1 \\
\hline$W$ & NC00471 & 907 & 915 & 899 & 16 & 18 \\
\hline$W$ & NCO0320 & 926 & 927 & 926 & 0 & 0.0 \\
\hline$w$ & NC00550 & 940 & 858 & 1022 & 164 & 17.5 \\
\hline$w$ & NC00615 & 953 & 963 & 943 & 21 & 2.2 \\
\hline$W$ & NC00997 & 953 & 915 & 992 & 77 & 8.0 \\
\hline$W$ & NC01488 & 992 & 998 & 986 & 12 & 12 \\
\hline W & NC00628 & 1024 & 1065 & 983 & 82 & 80 \\
\hline$W$ & $\mathrm{NCO} 1437$ & 1052 & 1010 & 1094 & 84 & 80 \\
\hline$W$ & NCO1191 & 1071 & 1164 & 978 & 186 & 173 \\
\hline$W$ & NCOI197 & 1077 & 1108 & 1046 & 63 & 5.8 \\
\hline$W$ & $\mathrm{NCO} 1037$ & 1113 & 1120 & 1105 & 15 & 14 \\
\hline $\mathrm{W}$ & NC01375 & 1113 & 1100 & 1126 & 27 & 24 \\
\hline$W$ & $\mathrm{NCOO533}$ & 1119 & 1148 & 1089 & 59 & 53 \\
\hline$W$ & $\mathrm{NCO} 1193$ & 1146 & 1171 & 1121 & 51 & 44 \\
\hline W & $\mathrm{NCO} 1001$ & 1164 & 1196 & 1133 & 63 & 54 \\
\hline$W$ & $\mathrm{NCO0404}$ & 1167 & 1189 & 1144 & 45 & 39 \\
\hline$W$ & NCO0509 & 1181 & 1162 & 1199 & 37 & 32 \\
\hline$W$ & NC00698 & 1182 & 1198 & 1166 & 32 & 2.7 \\
\hline$W$ & $\mathrm{NCO} 1298$ & 1186 & 1178 & 1193 & 16 & 1.3 \\
\hline$W$ & $\mathrm{NC} 00178$ & 1191 & 1111 & 1270 & 159 & 133 \\
\hline$W$ & $\mathrm{NC} 00674$ & 1225 & 1193 & 1258 & 65 & 53 \\
\hline$W$ & $\mathrm{NCO} 1317$ & 1228 & 1220 & 1235 & 14 & 12 \\
\hline$W$ & NC00746 & 1236 & 1257 & 1214 & 43 & 35 \\
\hline$W$ & NC01307 & 1239 & 1264 & 1213 & 51 & 41 \\
\hline$W$ & NCO1385 & 1248 & 53 & 2444 & 2392 & 1916 \\
\hline$W$ & NC01036 & 1278 & 1267 & 1290 & 23 & 18 \\
\hline$W$ & $\mathrm{NC00381}$ & 1283 & 1297 & 1269 & 28 & 2.2 \\
\hline$W$ & $\mathrm{NCO} 1439$ & 1296 & 1288 & 1305 & 17 & 1.3 \\
\hline$W$ & $\mathrm{NCO} 1427$ & .301 & 1303 & 1300 & 3 & 02 \\
\hline$W$ & $\mathrm{NCOO830}$ & 1302 & 1382 & 1223 & 159 & 12.2 \\
\hline$W$ & $\mathrm{NCO} 1142$ & 1307 & 1327 & 1288 & 39 & 30 \\
\hline$W$ & $\mathrm{NCO} 1304$ & 1316 & 1265 & 1366 & 101 & 7.7 \\
\hline$W$ & NC00953 & 1317 & 1283 & 1352 & 68 & 52 \\
\hline W & NC01018 & 1329 & 1368 & 1290 & 78 & 59 \\
\hline$W$ & $\mathrm{NCO0361}$ & 1364 & 1396 & 1332 & 64 & 47 \\
\hline$W$ & NC00949 & 1366 & 1362 & 1371 & 9 & 0.7 \\
\hline$W$ & NCO0729 & 1377 & 1409 & 1344 & 65 & 4.7 \\
\hline$W$ & NC00926 & 1404 & 1422 & 1387 & 35 & 2.5 \\
\hline$W$ & NC00977 & 1416 & 1458 & 1375 & 83 & 59 \\
\hline$W$ & NCO 01382 & 1422 & 1439 & 1405 & 34 & 24 \\
\hline
\end{tabular}




\begin{tabular}{|c|c|c|c|c|c|c|}
\hline REGION & HOUSE ID & $\mathrm{H2O} \mathrm{pCl} / \mathrm{L}$ & VIAL I & VIAL 2 & ABS DIFF & $\%$ DIFF \\
\hline$W$ & $\mathrm{NCO} 1380$ & 1425 & 1426 & 1423 & 3 & 0.2 \\
\hline$W$ & NC01078 & 1453 & 1412 & 1495 & 83 & 57 \\
\hline$W$ & $\mathrm{NCO0331}$ & 1481 & 1519 & 1443 & 76 & 51 \\
\hline$w$ & $\mathrm{NCOO231}$ & 1489 & 1454 & 1523 & 69 & 47 \\
\hline$W$ & $\mathrm{NC} 00274$ & 1496 & 1431 & 1560 & 129 & 86 \\
\hline$w$ & NC00810 & 1506 & 1520 & 1491 & 29 & 2.0 \\
\hline$w$ & $\mathrm{NCOO262}$ & 1520 & 1513 & 1529 & 16 & 11 \\
\hline$W$ & $N=00388$ & 1523 & 1471 & 1576 & 104 & 6.8 \\
\hline $\bar{W}$ & NC00869 & 1538 & 1605 & 1470 & 134 & 87 \\
\hline$w$ & NC00955 & 1581 & 1553 & 1609 & 56 & 35 \\
\hline$W$ & $\mathrm{NC00217}$ & 1003 & 1610 & 1596 & 14 & 09 \\
\hline$W$ & NC01091 & 1606 & 1594 & 1618 & 24 & 1.5 \\
\hline$W$ & NCo 1050 & 1610 & 1645 & 1576 & 68 & 42 \\
\hline$w$ & NC00930 & 1616 & 1654 & 1578 & 76 & 47 \\
\hline$W$ & $\mathrm{NCO} / 223$ & 1621 & 1589 & 1053 & 63 & 39 \\
\hline $\bar{W}$ & NC00534 & 1678 & 1664 & 1691 & 27 & 16 \\
\hline W & NC01061 & 1690 & 1751 & 1628 & 122 & 72 \\
\hline $\bar{W}$ & NC00409 & 1734 & 1845 & 1623 & 223 & 128 \\
\hline$W$ & $\mathrm{NCO} / 428$ & 1741 & 1808 & 1674 & 133 & 77 \\
\hline$W$ & $\mathrm{NC} 00504$ & 1744 & 1796 & 1692 & 104 & 60 \\
\hline W & NCO1109 & 1745 & 1756 & 1733 & 23 & 13 \\
\hline$W$ & NC00299 & 1777 & 1809 & 1745 & 65 & 36 \\
\hline W & $\mathrm{NC} 00429$ & 1783 & 1796 & 1770 & 26 & 15 \\
\hline$W$ & $\mathrm{NCO} 1347$ & 1787 & 1781 & 1794 & 13 & 0.7 \\
\hline$W$ & $\mathrm{NCO} 1418$ & 1825 & 1878 & 1772 & 106 & 58 \\
\hline$W$ & NCO1169 & 1828 & 1813 & 1844 & 31 & 17 \\
\hline$W$ & $\mathrm{NC} 00908$ & 1831 & 1817 & 1845 & 28 & 15 \\
\hline$W$ & $\mathrm{NCO} 1324$ & 1835 & 1845 & 1824 & 21 & 11 \\
\hline$W$ & NC00575 & 1853 & 1860 & 1846 & 14 & 07 \\
\hline W & $\mathrm{NC} 00814$ & 1890 & 1877 & 1902 & 24 & 13 \\
\hline$W$ & $\mathrm{NCO} 1526$ & 1892 & 1968 & 1816 & 152 & 80 \\
\hline$W$ & NCO1541 & 1923 & 1768 & 2078 & 310 & 16.1 \\
\hline$W$ & $\mathrm{NC} 00713$ & 1923 & 1787 & 2060 & 274 & 142 \\
\hline$W$ & $\mathrm{NC} 01392$ & 1990 & 2050 & 1931 & 119 & 60 \\
\hline$W$ & $\mathrm{NC} 00656$ & 1990 & 2094 & 1886 & 208 & 10.5 \\
\hline$W$ & NC01368 & 2003 & 1971 & 2035 & 64 & 3.2 \\
\hline$W$ & $\mathrm{NCO} 1371$ & 2007 & 2016 & 1999 & 16 & 08 \\
\hline$W$ & $\mathrm{NC} 01025$ & 2021 & 2000 & 2043 & 42 & 2.1 \\
\hline$W$ & NCO 1328 & 2167 & 2264 & 2070 & 193 & 89 \\
\hline$W$ & $\mathrm{NC} 00289$ & 2183 & 2165 & 2200 & 35 & 1.0 \\
\hline$W$ & NC00928 & 2188 & 2206 & 2170 & 37 & 1.7 \\
\hline$W$ & $\mathrm{NCO} 1159$ & 2189 & 2267 & 2110 & 157 & 72 \\
\hline
\end{tabular}




\begin{tabular}{|c|c|c|c|c|c|c|}
\hline REGION & HOUSE ID & $\mathrm{H} 20 \mathrm{nCl} / \mathrm{L}$ & VIAL I & VIAL 2 & ABS DIFF & $\%$ DIFF \\
\hline$W$ & $\mathrm{NCO0712}$ & 2231 & 2248 & 2214 & 34 & 15 \\
\hline$w$ & NCO0535 & 2298 & 2349 & 21.58 & 191 & 85 \\
\hline$W$ & $\mathrm{NC} 01256$ & 2324 & 2468 & 2179 & 289 & 124 \\
\hline$W$ & $\mathrm{NCOO401}$ & 2374 & 2360 & 2387 & 27 & 11 \\
\hline $\bar{W}$ & NC00996 & 2377 & 2440 & 2319 & 125 & 53 \\
\hline $\bar{W}$ & NC00264 & 2408 & 2393 & 2424 & 31 & 13 \\
\hline $\bar{w}$ & NCOI066 & 2409 & 2403 & 2414 & 11 & 05 \\
\hline $\bar{W}$ & NC00792 & 2442 & 2536 & 2347 & 189 & 77 \\
\hline$W$ & $\mathrm{NC} 00453$ & 2.510 & 2511 & 2509 & 2 & 01 \\
\hline 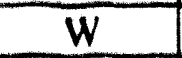 & $\mathrm{NC} 00777$ & 2516 & 2537 & 2494 & 43 & 17 \\
\hline $\bar{W}$ & NC00530 & 2555 & 2616 & 2494 & 122 & 48 \\
\hline$W$ & NC01458 & 2620 & 2625 & 2015 & 10 & 04 \\
\hline $\bar{W}$ & NC00893 & 2629 & 2582 & 2677 & 94 & 30 \\
\hline $\bar{W}$ & $\mathrm{NC} 00932$ & 2721 & 2747 & 2095 & 53 & 10 \\
\hline $\bar{W}$ & NCOO1345 & 2828 & 2818 & 28.38 & 20 & 07 \\
\hline$W$ & $\mathrm{NCO} 0415$ & 2846 & 2875 & 2817 & 58 & 20 \\
\hline$W$ & $\mathrm{NC} 00544$ & 3036 & 3118 & 2954 & 164 & 54 \\
\hline$w$ & NCO1388 & 3062 & 3140 & 2984 & 156 & 51 \\
\hline$W$ & $\mathrm{NC} 00045$ & 3090 & 3122 & 3058 & 64 & 21 \\
\hline $\bar{W}$ & NC00766 & 3199 & 3121 & 3277 & 156 & 40 \\
\hline$w$ & $\mathrm{NCOO446}$ & 3236 & 3263 & 3209 & 55 & 17 \\
\hline$w$ & $\mathrm{NCO} 1279$ & 3372 & 3537 & 3207 & 330 & 98 \\
\hline $\bar{w}$ & NC00450 & 3439 & 3414 & 3464 & 50 & 14 \\
\hline$w$ & $\mathrm{NC} 00307$ & 3552 & 3597 & 3507 & 90 & 25 \\
\hline$w$ & NC00776 & 3595 & 3694 & 3495 & 200 & 56 \\
\hline W & NCO0396 & 3628 & 3908 & 3349 & 559 & 154 \\
\hline$W$ & $\mathrm{NCO} 1145$ & 3634 & 3429 & 3838 & 409 & 113 \\
\hline$W$ & NCO1064 & 3971 & 4004 & 3940 & 64 & 16 \\
\hline $\bar{W}$ & $\mathrm{NCOO} 305$ & 4089 & 4026 & 4152 & 126 & 31 \\
\hline W & $\mathrm{NCO} 1172$ & 4095 & 4111 & 4080 & 30 & 07 \\
\hline W & NC00659 & 4212 & 4277 & 4148 & 129 & 31 \\
\hline$W$ & $\mathrm{NCO} 1239$ & 4228 & 4221 & 4236 & 14 & 03 \\
\hline$W$ & $\mathrm{NC} 01496$ & 4296 & 4215 & 4377 & 162 & 38 \\
\hline$W$ & NCO1326 & 4325 & 4333 & 4318 & 15 & 03 \\
\hline$W$ & $\mathrm{NCO} 1547$ & 4365 & 4316 & 4414 & 98 & 2.2 \\
\hline$W$ & $\mathrm{NCO} / 433$ & 4425 & 4432 & 4418 & 14 & 03 \\
\hline$W$ & $\mathrm{NCO} 1113$ & 4437 & 4392 & 4482 & 90 & 20 \\
\hline$W$ & $\mathrm{NCO} 1461$ & 4557 & 4575 & 4539 & 36 & 08 \\
\hline$W$ & NC00716 & 4680 & 4560 & 4801 & 241 & 52 \\
\hline$W$ & $\mathrm{NCO0425}$ & 468.5 & 4643 & 4728 & 85 & 1.8 \\
\hline$W$ & NCO0838 & 4754 & 4782 & 4726 & 55 & 1.2 \\
\hline $\bar{W}$ & NCO1199 & 4815 & 4848 & 4782 & 67 & 14 \\
\hline
\end{tabular}




\begin{tabular}{|c|c|c|c|c|c|c|}
\hline REGION & HOUSE ID & $\mathrm{H} 2 \mathrm{O} \mathrm{pCl} / \mathrm{L}$ & VIAL I & VIAL 2 & ABS DIFF & $\%$ DIFF \\
\hline W & $\mathrm{NC} 00924$ & 4830 & 4844 & 4816 & 28 & 06 \\
\hline$W$ & $\mathrm{NCO} 1111$ & 4912 & 4956 & 4867 & 90 & 18 \\
\hline$W$ & $\mathrm{NC} 01253$ & 5000 & 5010 & 4990 & 20 & 04 \\
\hline$W$ & $\mathrm{NC} 00753$ & 5097 & 5079 & 5115 & 36 & 07 \\
\hline$w$ & NCO1484 & 5639 & 5627 & 5650 & 23 & 04 \\
\hline$w$ & $\mathrm{NC00208}$ & 5789 & 5583 & 5994 & 410 & 71 \\
\hline$w$ & NCOI006 & 5839 & 5832 & 5846 & 14 & 02 \\
\hline W & $\mathrm{NCO} 1052$ & 5850 & 6270 & 5429 & 841 & 14.4 \\
\hline$W$ & $\mathrm{NCO} 1296$ & 5897 & 5939 & 5856 & 83 & 14 \\
\hline 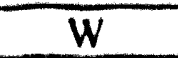 & NC00994 & 5914 & 5886 & 5942 & 56 & 10 \\
\hline$w$ & $\mathrm{NCO} 1274$ & 6064 & 6017 & 6110 & 94 & 16 \\
\hline W & NC00739 & 6151 & 6305 & 5997 & 309 & 51 \\
\hline$W$ & $\mathrm{NCO} 1155$ & 6314 & 6399 & 6230 & 170 & 27 \\
\hline $\bar{W}$ & NC00995 & 6693 & 6685 & 6702 & 17 & 0.3 \\
\hline$w$ & NC00757 & 6917 & 7015 & 6819 & 196 & 28 \\
\hline$w$ & $\mathrm{NC} 00663$ & 7089 & 7107 & 7071 & 37 & 0.5 \\
\hline$w$ & $\mathrm{NCO} 1278$ & 7445 & 7409 & 7481 & 71 & 10 \\
\hline W & NC00461 & 7662 & 7099 & 8225 & 1120 & 14.7 \\
\hline$w$ & NC00288 & 8192 & 8179 & 8205 & 26 & 0.3 \\
\hline$w$ & $\mathrm{NCO} 1093$ & 8483 & 8242 & 8724 & 482 & 57 \\
\hline W & $\mathrm{NCO} / 452$ & 8087 & 8257 & 8717 & 459 & 54 \\
\hline $\bar{W}$ & $\mathrm{NC} 00691$ & 86.37 & 8538 & 8737 & 200 & 2.3 \\
\hline$W$ & $\mathrm{NC} 01146$ & 10391 & 10509 & 10272 & 236 & 23 \\
\hline$W$ & $\mathrm{NCO} 1542$ & 10587 & 10776 & 10397 & 379 & 36 \\
\hline$w$ & $\mathrm{NCOO413}$ & 13872 & $1+193$ & 13551 & 642 & +0 \\
\hline W & $\mathrm{NCOO892}$ & 21122 & 21098 & 21146 & 48 & 02 \\
\hline$w$ & $\mathrm{NCO} 1255$ & 24357 & 23860 & 24855 & 996 & +1 \\
\hline $\bar{W}$ & $\mathrm{NC} 00552$ & 59088 & 58843 & 59333 & 490 & 08 \\
\hline
\end{tabular}

Concentrations rounded to nearest $\mathrm{pCi} \mathrm{L}^{-1}$ for water samples 